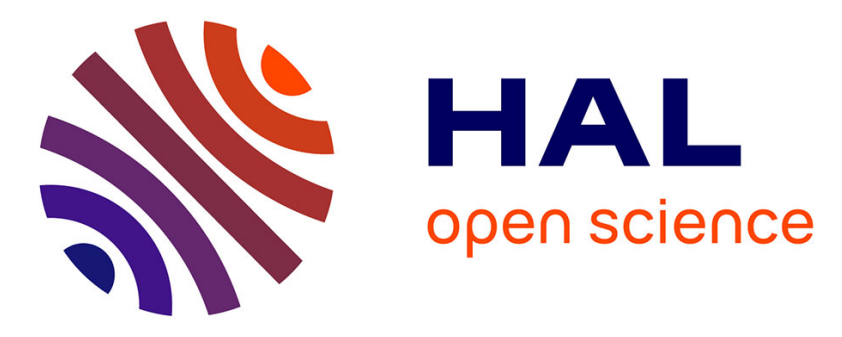

\title{
Neptunium redox speciation at the illite surface
}

\author{
Remi Marsac, Nidhu L Banik, Johannes Lützenkirchen, Christian M. \\ Marquardt, Kathy Dardenne, Dieter Schild, Joerg Rothe, Alexandre Diascorn, \\ Tomas Kupcik, Thorsten Schäfer, et al.
}

\section{- To cite this version:}

Remi Marsac, Nidhu L Banik, Johannes Lützenkirchen, Christian M. Marquardt, Kathy Dardenne, et al. Neptunium redox speciation at the illite surface. Geochimica et Cosmochimica Acta, 2015, 152, pp.39 - 51. 10.1016/j.gca.2014.12.021 . hal-01904147

\section{HAL Id: hal-01904147 https://hal.science/hal-01904147}

Submitted on 24 Oct 2018

HAL is a multi-disciplinary open access archive for the deposit and dissemination of scientific research documents, whether they are published or not. The documents may come from teaching and research institutions in France or abroad, or from public or private research centers.
L'archive ouverte pluridisciplinaire HAL, est destinée au dépôt et à la diffusion de documents scientifiques de niveau recherche, publiés ou non, émanant des établissements d'enseignement et de recherche français ou étrangers, des laboratoires publics ou privés. 


\section{Accepted Manuscript}

Neptunium redox speciation at the illite surface

Rémi Marsac, Nidhu lal Banik, Johannes Lützenkirchen, Christian Michael

Marquardt, Kathy Dardenne, Dieter Schild, Joerg Rothe, Alexandre Diascorn, Tomas Kupcik, Thorsten Schäfer, Horst Geckeis

PII:

S0016-7037(14)00742-X

DOI: http://dx.doi.org/10.1016/j.gca.2014.12.021

Reference:

GCA 9085

To appear in:

Geochimica et Cosmochimica Acta

Received Date:

10 June 2014

Accepted Date:

17 December 2014

Please cite this article as: Marsac, R., Banik, N.l., Lützenkirchen, J., Marquardt, C.M., Dardenne, K., Schild, D., Rothe, J., Diascorn, A., Kupcik, T., Schäfer, T., Geckeis, H., Neptunium redox speciation at the illite surface, Geochimica et Cosmochimica Acta (2015), doi: http://dx.doi.org/10.1016/j.gca.2014.12.021

This is a PDF file of an unedited manuscript that has been accepted for publication. As a service to our customers we are providing this early version of the manuscript. The manuscript will undergo copyediting, typesetting, and review of the resulting proof before it is published in its final form. Please note that during the production process errors may be discovered which could affect the content, and all legal disclaimers that apply to the journal pertain. 


\section{Neptunium redox speciation at the illite surface}

Rémi Marsac ${ }^{\mathrm{a}}$, Nidhu lal Banik*,a, Johannes Lützenkirchen ${ }^{\mathrm{a}}$, Christian Michael Marquardt ${ }^{\mathrm{a}}$, Kathy Dardenne ${ }^{\mathrm{a}}$, Dieter Schild ${ }^{\mathrm{a}}$, Joerg Rothe ${ }^{\mathrm{a}}$, Alexandre Diascorn ${ }^{\mathrm{a}}$, Tomas Kupcik ${ }^{\mathrm{a}}$, Thorsten Schäfer ${ }^{\mathrm{a}}$ and Horst Geckeis ${ }^{\mathrm{a}}$

*Corresponding author:

E-mail address: nidhu.banik@kit.edu

${ }^{\mathrm{a}}$ Institut für Nukleare Entsorgung, Karlsruhe Institute of Technology, P.O. Box 3640, D76021 Karlsruhe, Germany, Tel +4972160822420; Fax: +4972160823927 
ABSTRACT. Neptunium $(\mathrm{Np}(\mathrm{V}))$ sorption onto a purified illite is investigated as a function of $\mathrm{pH}(3-10)$ and $\left[\mathrm{Np}^{\mathrm{V}} \mathrm{O}_{2}^{+}\right]_{\mathrm{tot}}\left(3 \times 10^{-8}-3 \times 10^{-4} \mathrm{M}\right)$ in $0.1 \mathrm{M} \mathrm{NaCl}$ under Ar atmosphere. After about one week reaction time, only insignificant variation of $\mathrm{Np}$ sorption is observed and the establishment of reaction equilibrium can be assumed. Surprisingly, solid-liquid distribution ratios $\left(R_{d}\right)$ are clearly higher than those measured for $N p(V)$ sorption onto illite under aerobic conditions. The observation that $\mathrm{R}_{\mathrm{d}}$ increases with decreasing pe (pe $=-\log \mathrm{a}_{\mathrm{e}-\text { ) }}$ suggests partial reduction to $\mathrm{Np}(\mathrm{IV})$, although measured redox potentials (pe values) at a first glance suggest the predominance of $\mathrm{Np}(\mathrm{V})$. Reduction to $\mathrm{Np}(\mathrm{IV})$ at the illite surface could indeed be confirmed by X-ray absorption near-edge spectroscopy (XANES). Np speciation in presence of the purified Na-illite under given conditions is consistently described by applying the 2 sites protolysis non-electrostatic surface complexation and cation exchange model. Measured pe data are taken to calculate $\mathrm{Np}$ redox state and surface complexation constants for $\mathrm{Np}(\mathrm{IV})$ are derived by applying a data fitting procedure. Constants are very consistent with results obtained by applying an existing linear free energy relationship (LFER). Taking Np(IV) surface complexation constants into account shifts the calculated $\mathrm{Np}(\mathrm{V}) / \mathrm{Np}(\mathrm{IV})$ redox borderline in presence of illite surfaces by $3-5$ pe units $(0.2-0.3 \mathrm{~V})$ towards redox neutral conditions. Our study suggests that $\mathrm{Np}(\mathrm{V})$ reduction in presence of a sorbing mineral phase is thermodynamically favored.

Keywords: Neptunium, illite, redox, surface complexation, spectroscopy, geochemical modeling. 


\section{INTRODUCTION}

Neptunium (Np) is only a minor constituent of high level radioactive waste. Its environmental chemistry is still of considerable interest due to the long half-life of its main isotope ${ }^{237} \mathrm{~Np}\left(\mathrm{t}_{1 / 2}=2 \times 10^{6} \mathrm{a}\right)$ and its high solubility and mobility as pentavalent $\mathrm{Np}(\mathrm{V}) \mathrm{O}_{2}^{+}$ under oxidizing conditions. In general, Np can exist in oxidation states between + III and +VII in aqueous solution, but penta- and tetravalent $\mathrm{Np}$ are the most relevant oxidation states in the geosphere (Kim, 1986). $\mathrm{NpO}_{2}{ }^{+}$only weakly sorbs to mineral surfaces and is therefore regarded as rather mobile (Geckeis et al., 2013). Under reducing conditions, Np(IV) prevails and is considered as rather immobile because of its strong sorption to minerals and due to its low solubility, as other tetravalent actinides (An; e.g. Th(IV)) or other tetravalent elements (e.g. Sn(IV)) (Bradbury and Baeyens, 2009a,b).

Clay minerals are main components in sedimentary rocks, which are considered as potential host rocks for radioactive waste disposal (e.g. Callovo-Oxfordian mudstone, France; Opalinus Clay) (Claret et al., 2005; Latrille et al., 2006; Wu et al., 2009). Their high sorption capacity for cations via ion exchange reactions as well as surface complexation to silanol or aluminol groups at the edge of clay particles have a major impact on radionuclide and metal ion retention. Np sorption onto purified clay minerals has mostly been studied under aerobic conditions, where the $+\mathrm{V}$ oxidation state is dominant or under inert atmosphere but without monitoring or controlling the redox potential (Gorgeon, 1994; Turner, 1998; Amayri et al., 2011). As slightly reducing conditions are frequently found in soil or natural clay rocks, it is mandatory to assess the impact of redox conditions on the behavior of redox active metal ions such as $\mathrm{Np}$. Partial reduction of $\mathrm{Np}(\mathrm{V})$ to $\mathrm{Np}(\mathrm{IV})$ when in contact with Opalinus Clay was suggested by comparing sorption data obtained under aerobic and anaerobic conditions. Stronger Np sorption (Fröhlich et al., 2011) was found under anaerobic conditions and significant reduction to $\mathrm{Np}(\mathrm{IV})$ was evidenced by applying synchrotron based spectroscopic 
techniques (Fröhlich et al., 2012). Np(IV) was found associated with pyrite as the main reductant in the natural clay rock.

The oxidation state of the early actinides $(\mathrm{Pa}, \mathrm{U}, \mathrm{Np}, \mathrm{Pu})$ is determined by the redox potential in solution, which in turn is controlled by the balance of redox pairs (see e.g. Altmaier et al.,2013). Establishment of redox equilibria in homogeneous solution may however be slow. For instance, Nakata et al. (2002) observed almost no $\mathrm{Np}(\mathrm{V})$ reduction by dissolved Fe(II) after one week. By contrast, reactions with redox active solid phases are usually found to proceed fast (Stumm 1992; Buerge and Hug, 1999; Liger et al., 1999; Nakata et al., 2002; Charlet et al., 2007; Bach et al., 2014). Notably for reactions with $\mathrm{Pu}(\mathrm{V})$ with mineral surfaces rapid reduction to $\mathrm{Pu}(\mathrm{IV})$ is stated (Powell et al., 2004; 2005; Hixon et al., 2010; Kirsch et al., 2011; Zavarin et al., 2012). The time necessary for a complete Pu(V) reduction varies from few hours to few days depending on the mineral. Spectroscopic and microscopic examination very often reveal that reduced $\mathrm{Pu}(\mathrm{IV})$ species are predominantly found at the mineral surface, thus implying surface mediated reduction being the relevant reaction mechanism. Reduction is, however, also found at mineral surfaces where a specific reducing partner is absent (Hixon et al., 2013), suggesting that $\mathrm{Pu}(\mathrm{IV})$ under given conditions simply is the thermodynamically favored species. Zavarin et al. (2012) studied $\mathrm{Np}(\mathrm{V})$ sorption onto montmorillonite under the same conditions as for $\mathrm{Pu}(\mathrm{V})$, but did not observe $\mathrm{Np}(\mathrm{V})$ reduction. This observation can be explained by the fact that the standard redox potential of the $\mathrm{Np}(\mathrm{V}) / \mathrm{Np}(\mathrm{IV})$ couple $\left(E_{N p O_{2}^{+} / N p^{4+}}^{0}=0.604 \mathrm{~V}\right)$ is lower than that of the $\mathrm{Pu}(\mathrm{V}) / \mathrm{Pu}(\mathrm{IV}) \operatorname{pair}\left(E_{\mathrm{PuO}_{2}^{+} / \mathrm{Pu}^{4+}}^{0}=1.031 \mathrm{~V}\right)($ Guillaumont et al., 2003). Therefore, reduction of $\mathrm{Np}(\mathrm{V})$ to $\mathrm{Np}(\mathrm{IV})$ in presence of montmorillonite surfaces under given conditions apparently is not thermodynamically favorable.

Only a few attempts are reported in the literature to describe actinide redox reactions in presence of minerals quantitatively by applying mechanistic surface complexation models. 
Such thermodynamic models are particularly relevant and required for a comprehensive prediction of actinide behavior in natural systems. Degueldre and Bolek (2009) discussed Pu sorption to $\mathrm{Al}_{2} \mathrm{O}_{3}, \mathrm{FeOOH}$ and $\mathrm{SiO}_{2}$ colloids based on a simple $\mathrm{R}_{\mathrm{d}}$ approach. Their calculations included the effect of the redox potential, which was shown to have a major impact on calculated Pu uptake data. Schwantes and Santschi (2010) proposed a surface complexation model involving all $\mathrm{Pu}$ redox states (from $+\mathrm{III}$ to $+\mathrm{VI}$ ) to minerals and a reversible surface mediated $\mathrm{Pu}(\mathrm{V})-\mathrm{Pu}(\mathrm{IV})$ reaction to explain the observed kinetics of $\mathrm{Pu}$ uptake. Experimentally determined redox potential (pe; Eh) or $\mathrm{O}_{2(\mathrm{~g})}$ partial pressures are essential for the application of surface complexation models to describe sorption behavior of redox sensitive elements. However, in most studies mentioned above, such data are not provided, very often due to difficulties associated with their experimental determination (Schüring et al., 2000;Altmaier et al., 2010).

The present study is dedicated to $\mathrm{NpO}_{2}{ }^{+}$sorption to a purified clay mineral (illite) under inert gas atmosphere (Argon) in order to exclude the influence of atmospheric $\mathrm{CO}_{2}$. Classical batch experiments at various $\mathrm{pH}$, total $\mathrm{Np}$ concentrations and reaction times are performed and compared with literature data for the uptake of various metal ions onto illite. Different to many other similar studies a special focus is dedicated to monitor redox conditions. X-ray absorption near edge structure spectroscopy (XANES) is applied to determine the Np redox state at the illite surface. Finally, an attempt is made to consistently describe $\mathrm{Np}$ sorption and redox speciation using surface complexation modeling.

\section{MATERIALS AND METHODS}

All chemicals are of pro analytical quality or better and were obtained from Merck (Darmstadt, Germany) or Riedel de Haen (Seelze, Germany). All experiments were conducted 
with de-ionized "MilliQ" water (specific resistivity, $18.2 \mathrm{M} \Omega \mathrm{cm}^{-1}$ ). The aqueous concentration of ${ }^{237} \mathrm{~Np}$ was analyzed using LSC with a TriCarb 3100 (Beckman/PerkinElmer) and the scintillation cocktail Ultima Gold XR (Packard Instruments Co., USA). To differentiate between the alpha decay of the ${ }^{237} \mathrm{~Np}$ and the beta decay of its daughter ${ }^{233} \mathrm{~Pa}$, the measurements have been performed in an alpha-beta discrimination mode applying a Pulse Decay Analysis (PDA), a form of pulse shape analysis, to perform differentiation of alpha and beta events. PDA uses a time based Pulse Decay Discriminator (PDD) to evaluate the pulse duration of scintillation events and categorize the events as either alpha or beta. A discriminator (146) setting was used to reduce the beta spillover to $1.50 \% .{ }^{237} \mathrm{~Np}$ counting efficiencies for each sample were determined using a ${ }^{237} \mathrm{~Np}$ quenching curve. Each sample was counted for a total of $0.5 \mathrm{~h}$. Since we used a constant background electrolyte $(0.1 \mathrm{M}$ $\mathrm{NaCl}$ ), the Quench Indicating Parameter (QIP) tSIE - fixed to 470 - does not change significantly $( \pm 10)$ during the LSC measurements. Details about the LSC measurement are given in the supplementary information. In addition, the stock solution of ${ }^{237} \mathrm{~Np}$ and aqueous concentration of ${ }^{237} \mathrm{~Np}$ in the batch sorption experiment after phase separation were also checked at random by ICP-MS measurements and the results are in good agreement with LSC measurements.

\subsection{Neptunium stock solution}

The initial ${ }^{237} \mathrm{~Np}$ solution was evaporated to dryness and dissolved in $8 \mathrm{M} \mathrm{HCl}$. The solution was purified via anion exchange (BIO RAD ${ }^{\circledR}$ AG 1-X8). After a washing step with several milliliters of $8 \mathrm{M} \mathrm{HCl}, \mathrm{Pu}$ contaminations were removed with a fresh solution of 150 $\mathrm{mg} \mathrm{NH} 4 \mathrm{I}$ in $5 \mathrm{~mL} 8 \mathrm{M} \mathrm{HCl}$. Subsequently, $\mathrm{Np}$ was eluted from the ion exchanger with $4 \mathrm{M}$ $\mathrm{HCl} / 0.05 \mathrm{M} \mathrm{HF}$ and evaporated to dryness in a PTFE beaker. For all sorption experiments, stock solutions of neptunium in the pentavalent oxidation state were to be used. To obtain a solution containing only $\mathrm{NpO}_{2}{ }^{+}$, the solution was fumed twice with $1 \mathrm{M} \mathrm{HClO}_{4}$ and the 
residue was dissolved in deionized water. The pentavalent oxidation state of $\mathrm{NpO}_{2}{ }^{+}$was obtained by potentiostatic electrolysis and its purity was verified by UV-Vis/NIR spectroscopy (Sjoblom and Hindman 1951). The final Np concentration was determined by LSC.

\subsection{Illite preparation and characterization}

Purified Na-illite was used in this work and was provided within the EC project CP CatClay (www.catclay.org). The source material is derived from lacustrine continental sediments deposited at the Upper Eocene ( -35 Ma) in the basin of Le PuyenVelay (Massif Central, France). The clay formation in this region is mainly composed of illite with small contributions of kaolinite, a 1:1 clay mineral. In addition to kaolinite, K-feldspar, quartz and calcite are present in varying amounts (between 0 and $40 \%$; Gabis et al., 1963). The $<63 \mu \mathrm{m}$ size fraction was obtained by grinding and sieving the raw material (Poinssot et al., 1999). The purification procedure aims at removing non-clay (Ca-rich) mineral phases and converting the illite to the Na-form. The received illite material was equilibrated in a formate buffer solution (0.05 $\mathrm{M}$ formic acid and $0.05 \mathrm{M}$ Na-formate in $1 \mathrm{M} \mathrm{NaCl}, \mathrm{pH} \sim 3.5)$ at a mass to volume ratio $(\mathrm{m} / \mathrm{V})$ of $100 \mathrm{~g} / \mathrm{L}$ for 4 hours by gentle magnetic stirring. The solid phase was separated by centrifugation (500 $\mathrm{g}$ for 5 minutes), re-suspended in $1 \mathrm{M} \mathrm{NaCl}$ and equilibrated overnight (gentle magnetic stirring). This washing procedure was applied three times. After removing $80-85 \%$ of the liquid phase, the settled suspension was transferred into dialysis tubes and dialyzed against MilliQ water. The external solution was replaced twice daily, until no $\mathrm{NaCl}$ was detectable in the external solution (checked by adding $\mathrm{AgNO}_{3}$ ). In the last step, the clay suspensions were freeze dried. The characterization of the illite material is given in the supporting information file. The illite contains 7 wt.\% $\mathrm{Fe}_{2} \mathrm{O}_{3}$.

\subsection{Determination of $\mathrm{pH}$ and $\mathrm{Eh}$}


The $\mathrm{pH}$ in the clay suspensions was measured by an Orion 525A pH meter with a Ross electrode calibrated with 4 standard buffers ( $\mathrm{pH} \mathrm{3,5,7}$ and 9; Merck). The error of $\mathrm{pH}$ measurements is \pm 0.05 . The redox potentials in the clay suspensions were measured using an Orion 525A ( $\mathrm{E}_{\mathrm{h}}$ meter) and a $\mathrm{Pt}$ combined electrode with $\mathrm{Ag} / \mathrm{AgCl}$ reference system (Metrohm) and converted into Eh vs. standard hydrogen electrode (SHE) by correcting for the potential of the reference electrode. A commercial redox-buffer (220 mV, Schott instruments) was used for calibration. An equilibration time of 15 min was applied for all Eh measurements. The suspension was stirred prior to the Eh measurement. Uncertainties in Eh measurements lie in a range of $\pm 50 \mathrm{mV}$ (Altmaier et al., 2010; Kirsch et al., 2011). Eh was converted to the apparent electron activity, pe $=-\log \mathrm{a}_{\mathrm{e}-}=16.9 \times \mathrm{Eh}(\mathrm{V})$ at $25^{\circ} \mathrm{C}$, and the error of pe data is equal to around \pm 0.8 .

\subsection{Batch sorption experiments}

All sorption experiments were performed as batch type experiments at initial $\mathrm{Np}(\mathrm{V})$ concentrations in the range of $3 \times 10^{-8}-3 \times 10^{-4} \mathrm{M}$. Maximum $\mathrm{Np}$ concentration is below the solubility limit of relevant $\mathrm{Np}(\mathrm{V})$-bearing solids (Guillaumont et al., 2003). The batch experiments were carried out in $40 \mathrm{~mL}$ polypropylene centrifuge tubes at room temperature in an argon gloye box $\left(<1 \mathrm{ppm} \mathrm{O}_{2}\right.$, absence of $\left.\mathrm{CO}_{2}\right)$. The sample volume was $25 \mathrm{~mL}$. At a solid to liquid ratio of $2 \mathrm{~g} / \mathrm{L}$, the suspensions were preconditioned in $0.1 \mathrm{M} \mathrm{NaCl}$ by shaking continuously for 4-5 days to achieve a given target $\mathrm{pH}$ value by adding $0.1 \mathrm{M} \mathrm{HCl}$ or $0.1 \mathrm{M}$ $\mathrm{NaOH}$. After mixing the $\mathrm{NpO}_{2}{ }^{+}$solution with the preconditioned illite suspension, $\mathrm{pH}$ was readjusted by adding acid or base $(\mathrm{HCl} / \mathrm{NaOH})$. The samples were shaken end-over-end and $\mathrm{Np}$ sorption was followed with time after the addition of $\mathrm{NpO}_{2}{ }^{+}$to the illite suspension. After 7, 21, 35 and 63 days, $\mathrm{pH}$ and Eh were measured in the suspension and an aliquot of each sample was centrifuged in a Beckman L7 Ultracentrifuge at $90000 \mathrm{rpm}$ for $1 \mathrm{~h}$. The supernatant was analyzed for dissolved Np by LSC. Results obtained in batch experiments 
will be expressed throughout as distribution coefficients $\left(R_{d}\right.$ in $\left.L / k g\right)$, calculated by the following equation:

$\mathrm{R}_{\mathrm{d}}=\left([\mathrm{Np}]_{\mathrm{tot}} /[\mathrm{Np}]_{\mathrm{aq}}-1\right) \times \mathrm{V} / \mathrm{m}$

where $[\mathrm{Np}]_{\mathrm{aq}}$ and $[\mathrm{Np}]_{\mathrm{tot}}(\mathrm{mol} / \mathrm{L})$ are the dissolved (final) equilibrium and total (initial) concentrations of $\mathrm{Np}$ in solution, respectively. The term $\mathrm{V} / \mathrm{m}$ corresponds to the aqueous solution volume to illite mass ratio $(\mathrm{L} / \mathrm{kg}$ ). An uncertainty of \pm 0.3 is commonly associated with $\log \mathrm{R}_{\mathrm{d}}$ determination for radionuclide sorption to clay minerals (Bradbury and Baeyens, 2009a), although for low [Np $]_{\text {tot }}$ and high uptake, the uncertainty on $\log \mathrm{R}_{\mathrm{d}}$ might be higher.

A test experiment was performed to determine the oxidation state of $\mathrm{Np}(\mathrm{i})$ for a solution in contact with illite and (ii)for the illite surface via two liquid-liquid extraction methods using either 1-phenyl-3-methyl-4-benzoylpyrazolone-5 (PMBP)or phosphoric acid bis-(2-ethyl-hexyl) ester) (HDEHP) (Bertrand and Choppin 1982, Nitsche et al., 1988;1994) as extracting agents. For our experimental conditions, both methods are equivalent: PMBP extracts $\mathrm{Np}(\mathrm{IV})$ whereas HDEHP extracts $\mathrm{Np}(\mathrm{V})$ in organic phase at $\mathrm{pH}=0$. Results obtained with both methods were in good agreement. The experiment was carried out under Ar atmosphere. One sample $\left(\mathrm{pH}=7.0 ;[\mathrm{Np}]_{\mathrm{tot}}=10^{-5} \mathrm{M} ;[\mathrm{NaCl}]=0.1 \mathrm{M} ; \mathrm{m} / \mathrm{V}=2 \mathrm{~g} / \mathrm{L}\right)$ was filtered using $10 \mathrm{kDa}$ filters $(5000 \mathrm{rpm}$ for $1 \mathrm{~h}$ ) after one week contact time to separate solid from solution. To $0.6 \mathrm{~mL}$ portion of the filtrate solution $0.2 \mathrm{~mL} 2 \mathrm{M} \mathrm{HCl}$ and either $0.8 \mathrm{~mL}$ 0.025 M PMBP in Xylene or 0.5 M HDEHP in Toluene was added and then vigorously shaken for 10 min. The aqueous and organic phases were separated by centrifugation for 30 $\min (5000 \mathrm{rpm})$ and aliquots of each phase were taken for radiometric analysis. The solid (i.e. illite) was re-suspended in $1 \mathrm{M}$ HClfor2 days. Then the phases were separated by ultrafiltration $(10 \mathrm{kDa})$. The mass of solid that was recovered from the filter was not 
determined so the faction of $\mathrm{Np}$ desorbed in $1 \mathrm{M} \mathrm{HCl}$ cannot be determined. Only the redox speciation of $\mathrm{Np}$ in the desorbed fraction is obtained and discussed.

\subsection{X-ray absorption near-edge spectroscopy (XANES)}

Two samples were prepared as described in the previous section for $\mathrm{Np}_{3}$-XANES measurements. Initial conditions were $\left[\mathrm{NpO}_{2}{ }^{+}\right]_{\text {tot }}=3 \times 10^{-4} \mathrm{M}, \mathrm{m} / \mathrm{V}=20 \mathrm{~g} / \mathrm{L}$. Although XANES analysis requires higher $\mathrm{Np}$ concentration than those studied in the sorption experiments, the spectroscopic study yields direct evidence as to whether $\mathrm{Np}$ redox speciation is affected in the presence of illite. The final $\mathrm{pH}$ values were 7.4 and 9.6, respectively, for the two samples, and Eh was $0.40 \pm 0.05 \mathrm{~V}$ (pe $=6.8 \pm 0.8$ ) for both samples. An aliquot of each sample was centrifuged at $3000 \mathrm{~g}$ in a polyethylenevial $(500 \mu \mathrm{L})$. The supernatant was discarded and an aliquot was taken for LSC. The wet illite paste was transferred into a vial, mounted inside an Ar-flushed cell which acts as second containment, keeping sample vials in an anaerobic atmosphere (Brendebach et al., 2009). Measurements were performed at the 2.5 $\mathrm{GeV}$ synchrotron light source ANKA, KIT, Germany, at the INE-Beamline for actinide research (Rothe et al., 2006;2012). A pair of Ge(422) crystals was used in the Lemonnier-type double crystal monochromator (DCM). The monochromatic radiation is focused by a Rhcoated to roidal mirror into a spot of $<1 \mathrm{~mm} \times 1 \mathrm{~mm}$ at the sample position. Higher harmonic radiation in the incident beam was suppressed by detuning the parallel alignment of the DCM crystals to $70 \%$ of photon flux peak intensity in the middle of the spectral range at the beginning of each scan. The incident flux was measured by an Ar-filled ionization chamber at ambient pressure and held constant by a digital MOSTAB feedback system. The $\mathrm{Np}_{3}$-edge spectra $\left(E\left(\mathrm{~Np}^{0} 2 \mathrm{p}_{3 / 2}\right)=17.61 \mathrm{keV}\right)$ were calibrated against the first derivative XANES spectrum of a $\mathrm{Zr}$ foil (energy of the first inflection point set to $\left.\mathrm{E}\left(\mathrm{Zr}^{0} 1 \mathrm{~s}\right)=17.998 \mathrm{keV}\right)$. All 
$\mathrm{Np} \mathrm{L}_{3}$-XANES spectra were recorded in fluorescence detection mode by registering the $\mathrm{Np} \mathrm{L}_{\alpha}$ fluorescence yield at $\sim 13.95 \mathrm{keV}$ as a function of the incident photon energy with a 5-pixel Ge solid state detector (Canberra LEGe). Up to 5scans were collected at room temperature and averaged for each sample. The illuminated area of the sample was changed between each scan to minimize potential $\mathrm{Np}$ redox reactions induced by the beam. XANES spectra were isolated from XAFS scans following subtraction of a linear pre-edge background function and normalization of the edge jump to unity using the Demeter Athena software (Ravel and Newville, 2005).

\subsection{Thermodynamic modeling}

pe-pH diagrams for $\mathrm{Np}$ were obtained using PhreePlot (Kinniburgh and Cooper, 2009), which contains an embedded version of the geochemical speciation program PHREEQC (Parkhurst and Appelo, 1999). PhreePlot also includes a parameter optimization procedure, which automatically fits a model to experimental data by minimizing the weighted sum of squares of the residuals. A modified Marquardt-Levenberg procedure (Powell, 1965) was applied. With this method, PhreePlot provides also a statistical uncertainty of the estimated parameters. Thermodynamic constants for $\mathrm{Np}$ aqueous speciation were taken from the NEA thermodynamic database (Guillaumont et al., 2003). The 2-siteprotolysis nonelectrostatic surface complexation and cation exchange model (2 SPNE SC/CE model) was used to simulate Np sorption to illite (Bradbury and Baeyens, 2009b). The cation exchange capacity (CEC) of the illite was set equal to $0.225 \mathrm{eq} / \mathrm{kg}$. Two types of proton active sites are necessary to describe the titration data, but only one type is assumed by the model approach to bind cations. Among these cation binding sites, weak sites $\left([\equiv \mathrm{WOH}]=4 \times 10^{-2} \mathrm{~mol} / \mathrm{kg}\right)$ as well as less abundant strong sites $\left([\equiv \mathrm{SOH}]=2 \times 10^{-3} \mathrm{~mol} / \mathrm{kg}\right)$ are defined in this model with the same acid-base properties. Bradbury and Baeyens (2009b) determined a $\mathrm{NpO}_{2}^{+}-\mathrm{Na}^{+}$ 
selectivity coefficient as well as $\mathrm{Np}(\mathrm{V})$ surface complexation constants for illite within the 2 SPNE SC/CE model. Due to the weak $\mathrm{Np}(\mathrm{V})$ sorption to illite, leading to low surface coverage, only $\mathrm{Np}(\mathrm{V})$ surface complexation constants for the strong sites were determined. Bradbury and Baeyens (2009b) derived a linear free energy relationship (LFER) for the strong sites in the 2SPNE SC/CE model, which can be used to estimate surface complexation constants for cations, where experimental data are not available. LFER relates the hydrolysis constants of metal ions $\left({ }^{\mathrm{OH}} \mathrm{K}_{\mathrm{x}}\right.$, where $\mathrm{x}$ represents the number of $\mathrm{OH}^{-}$in the complex, eq. 2$)$ to their surface complexation constants $\left({ }^{\mathrm{S}} \mathrm{K}_{\mathrm{x}-1}\right.$, eq. 3$)$ :

$$
\begin{aligned}
& \mathrm{M}^{\mathrm{n}+}+\mathrm{x} \mathrm{H}_{2} \mathrm{O}=\mathrm{M}(\mathrm{OH})_{\mathrm{x}}{ }^{(\mathrm{n}-\mathrm{x})}+\mathrm{x} \mathrm{H}^{+} ;{ }^{\mathrm{OH}} \mathrm{K}_{\mathrm{x}} \\
& \equiv \mathrm{SOH}+\mathrm{M}^{\mathrm{n}+}+(\mathrm{x}-1) \mathrm{H}_{2} \mathrm{O}=\equiv \mathrm{SOM}(\mathrm{OH})_{(\mathrm{x}-1)}{ }^{(\mathrm{n}-\mathrm{x})}+\mathrm{x} \mathrm{H}^{+} ;{ }^{\mathrm{S}} \mathrm{K}_{(\mathrm{x}-1)} \\
& \left.\log { }^{\mathrm{S}_{\mathrm{K}}} \mathrm{x}-1\right)=7.9 \pm 0.4+(0.83 \pm 0.02) \times \log { }^{\mathrm{OH}} \mathrm{K}_{\mathrm{x}}
\end{aligned}
$$

Equation (4) represents the LFER where $\mathrm{M}^{\mathrm{n}+}$ is a metal ion with a charge of $+\mathrm{n}$. In the present study, the LFER is used to estimate surface complexation constants for $\mathrm{Np}(\mathrm{IV})$. These constants will be used as a starting point when fitted to the present experimental data using PhreePlot. A weight of 1 will be applied to all data. The error between experimental and modelled $R_{d}$ values (with the fitted constant showing the best fit) is recalculated as the root mean squared deviation (RMSD). A summary of all parameters for the 2SPNE SC/CE model used in the present study is given in table 1 . Additional information provided in table 1 will be discussed below.

\section{RESULTS AND DISCUSSION}

\subsection{Experimental Np-illite sorption data}


Figure 1 presents $\mathrm{Np}$ sorption to illite $\left(\mathrm{R}_{\mathrm{d}} \mathrm{in} \mathrm{L} / \mathrm{kg}\right.$ ) as a function of $\mathrm{pH}$ (i.e. $\mathrm{pH}$-edge). Only the highest and the lowest $\mathrm{Np}$ total concentrations investigated in the present study at various $\mathrm{pH}$ are presented here: $[\mathrm{Np}]_{\text {tot }}=10^{-6} \mathrm{M}$ (fig. 1a) and $3 \times 10^{-8} \mathrm{M}$ (fig. 1b). Results obtained for intermediate $[\mathrm{Np}]_{\text {tot }}$ are consistent with those data. The complete dataset is provided within the supplementary file. $R_{d}$ values determined after different reaction times $(7$, 21, 35 and63 days) are presented. For comparable $\mathrm{pH}$, no clear evolution of $\mathrm{R}_{\mathrm{d}}$ values with time for the two total $\mathrm{Np}$ concentrations presented here is observed after 7 days. For $[\mathrm{Np}]_{\mathrm{tot}}=$ $10^{-6} \mathrm{M}$ (fig. 1a), most of the data being recorded for $\mathrm{pH}<8$ show only a small increase of $\mathrm{R}_{\mathrm{d}}$ with $\mathrm{pH}$, which is consistent with the weak surface complexation of $\mathrm{Np}(\mathrm{V})$ at the edges of clay particles. For $[\mathrm{Np}]_{\text {tot }}=3 \times 10^{-8} \mathrm{M}$ (fig. $1 \mathrm{~b}$ ) and $\mathrm{pH}<6, \mathrm{R}_{\mathrm{d}}$ values are relatively similar to those measured at higher metal ion concentration. However, a significant increase of $R_{d}$ is observed for $\mathrm{pH}>6$ with values being 1 to 2 orders of magnitude higher than for experiments with $[\mathrm{Np}]_{\text {tot }}=10^{-6} \mathrm{M}$. Slightly more scattering $\mathrm{R}_{\mathrm{d}}$ values are observed for $[\mathrm{Np}]_{\mathrm{tot}}=3 \times 10^{-8} \mathrm{M}$ but the sorption results are reproducible within an experimental uncertainty for $\log \mathrm{R}_{\mathrm{d}}$ of about \pm 0.5 . When increasing $[\mathrm{Np}]_{\text {tot }}, \mathrm{pH}$-edges are shifted to higher $\mathrm{pH}$, i.e. a decrease of $\mathrm{R}_{\mathrm{d}}$ with increasing $[\mathrm{Np}]_{\text {tot }}$ is observed at a given $\mathrm{pH}$. This is consistent with non-ideal sorption behavior of $\mathrm{Np}$. Sorption data for $\mathrm{pH}=7.2 \pm 0.2$ are plotted as $\log \mathrm{R}_{\mathrm{d}}$ versus $\log [\mathrm{Np}]_{\mathrm{tot}}$ in figure 1c, which further illustrates the non-ideal sorption behavior.

\subsection{Comparison with the sorption behavior of other metal ions}

Sorption isotherms for various metal ions recorded at $\mathrm{pH}=7.2 \pm 0.2$ are plotted in figure 2. In the logarithmic plot, our Np sorption data follow a linear relationship with a slope of approximately 0.4, which indicates non-ideal sorption behavior (Freundlich, 1909). This means that either various surface sites are present or more than one sorption mechanism occurs. Our experimental results are compared with $\mathrm{Sr}(\mathrm{II})-, \mathrm{Ni}(\mathrm{II})-$ and $\mathrm{Eu}(\mathrm{III})$-illite sorption 
isotherms for $\mathrm{pH}=7$, in $0.1 \mathrm{M} \mathrm{NaNO}_{3}, \mathrm{NaCl}$ or $\mathrm{NaClO}_{4}$ ) (Poinssot et al., 1999; Bradbury and Baeyens 2005) taken from the literature. We included a data set for U(VI) sorption onto montmorillonite (Marques-Fernandez et al., 2012) at $\mathrm{pH}=6.8$ as data for illite at $\mathrm{pH} \approx 7$ are not available. The two clay minerals have similar sorption properties at $\mathrm{pH}=7$. Although the cations shown in figure 2 have very different chemical behavior, they all exhibit linear sorption isotherms (slope $~ 1$ ) up to a surface coverage of approximately $10^{-3} \mathrm{~mol} / \mathrm{kg}$ where the so-called "strong sites" dominate cation surface speciation (e.g. Bradbury and Baeyens, 2009a,b). The observed non-ideal Np-illite sorption isotherm down to $10^{-5} \mathrm{~mol} / \mathrm{kg}$ is therefore inconsistent with data reported for other cations and opposes the assumption of a pronounced site heterogeneity and rather suggests the existence of different sorption mechanisms.

Figure 3 compares sorption data obtained within the present study $\left([\mathrm{Np}]_{\mathrm{tot}}=1.2 \times 10^{-7}\right.$ $\mathrm{M}, \mathrm{m} / \mathrm{V}=2 \mathrm{~g} / \mathrm{L}$; data are not shown in figure 1)with those reported by Gorgeon (1994) for illite obtained under aerobic conditions and $\left[\mathrm{NaClO}_{4}\right]=0.1 \mathrm{M}\left([\mathrm{Np}]_{\text {tot }}=10^{-6} \mathrm{M}, \mathrm{m} / \mathrm{V}=10\right.$ $\mathrm{g} / \mathrm{L})$. Additionally, a comparison with reported $\mathrm{Np}$ sorption data on montmorillonite is provided in figure S3 (data form Gorgeon 1994; Turner et al., 1998; Bradbury and Baeyens, 2006), which corroborate the following interpretation. Gorgeon's $R_{d}$ values lie clearly below the data obtained in our study. A possible reason for the difference might be, that the influence of atmospheric $\mathrm{CO}_{2}$ and concomitant Np-carbonate complexation cannot be excluded completely in the experiments of Gorgeon (1994), even though contact with atmospheric $\mathrm{CO}_{2}$ was limited by capping the sample after $\mathrm{pH}$ adjustment. Turner et al. (1998) observed that atmospheric $\mathrm{CO}_{2}$ decreased $\mathrm{Np}(\mathrm{V})$ sorption to montmorillonite only at $\mathrm{pH}>8$ (Fig. S3). Therefore, the impact of $\mathrm{CO}_{2}$ on Gorgeon's data for $\mathrm{Np}(\mathrm{V})$ sorption onto illite should be of minor importance. Sorption to accessory minerals left over from incomplete purification appears very unlikely in our experiments. Such mineral phases could not be identified by XRD. Also, by comparison with literature data for $\mathrm{Np}(\mathrm{V})$ sorption onto 
montmorillonite (Fig. S3), which shows a higher CEC than illite, some of our $\mathrm{R}_{\mathrm{d}}$ data are by one order of magnitude higher for $\mathrm{pH}<6$. According to Bradbury and Baeyens (2009b) $\mathrm{Np}(\mathrm{V})$ sorption onto illite is controlled by cation exchange at $\mathrm{pH}<6$. They simulated the results of Gorgeon (1994) using a selectivity coefficient for the exchange of $\mathrm{Na}^{+}$by $\mathrm{NpO}_{2}^{+}$equal to 1 . Such a coefficient appears to be reasonable for the 1:1 exchange of cations with a formal charge of +1 . A similar treatment with our data would lead to $\mathrm{NpO}_{2}{ }^{+}-\mathrm{Na}^{+}$exchange constants in a range of 30 to 100 . Neither the presence of $\mathrm{CO}_{2}$ nor minor impurities can explain such observation. The major difference between Gorgeon's and our experiments is the different atmospheres: Gorgeon kept the samples under under air (oxidizing conditions) while the present results were obtained in an Ar-glovebox. A comparison with sorption data obtained for Th(IV) (Bradbury and Baeyens, 2009b) (figure 3) shows that our $R_{d}$ values appear to fall in between those for $\mathrm{Np}(\mathrm{V})$ and $\mathrm{Th}(\mathrm{IV})$. This may hold as a first indication for the partial reduction of $\mathrm{Np}(\mathrm{V})$ to $\mathrm{Np}(\mathrm{IV})$ under our experimental conditions. Another hint in this direction is given in figure 4 which contains $\log \mathrm{R}_{\mathrm{d}}$ plotted versus pe for $\mathrm{Np}$ sorption at $\mathrm{pH}=$ $7.2 \pm 0.2$. Despite the relatively large experimental uncertainty for pe, there is a clear correlation of $\log R_{d}$ increasing with decreasing pe. Lowest pe values are measured for those samples with lowest total $\mathrm{Np}$ concentrations. In other words, $\mathrm{Np}(\mathrm{V})$ reduction becomes predominant at low total metal concentrations and thus is responsible for the non-ideal sorption isotherm (fig. 1c or 2).Furthermore, the total $\mathrm{Np}$ concentration seems to influence the measured pe value. Interestingly, the slope of $\log R_{d}$ versus pe approximates unity, which is consistent with the reduction of $\mathrm{Np}(\mathrm{V})$ to $\mathrm{Np}(\mathrm{IV})$ by a one electron transfer mechanism.

Finally, a redox state analysis applied to one of the samples $\left(\mathrm{pH}=7.0 ;[\mathrm{Np}]_{\mathrm{tot}}=10^{-5} \mathrm{M}\right.$; $[\mathrm{NaCl}]=0.1 \mathrm{M} ; \mathrm{m} / \mathrm{V}=2 \mathrm{~g} / \mathrm{L})$ also corroborates the partial reduction of $\mathrm{Np}(\mathrm{V})$ to $\mathrm{Np}(\mathrm{IV})$ on the illite surface. After one week contact time, only $\mathrm{Np}(\mathrm{V})$ is found in solution $(93 \pm 10 \%)$. After re-suspending the illite in $1 \mathrm{M} \mathrm{HCl}$ for 2 days, a significant amount of the desorbed $\mathrm{Np}$ 
is found to be $\mathrm{Np}$ (IV) $(41 \pm 10 \%)$. As stated before, the amount of $\mathrm{Np}$ that may have remained on the illite after the acid treatment was not determined. However, $\mathrm{Np}(\mathrm{V})$ sorbs weakly to minerals and should be more easily desorbed than the strongly adsorbing $\mathrm{Np}$ (IV) (Powell et al., 2004; 2005). If $\mathrm{Np}$ remained sorbed after the acid treatment, it would be very likely $\mathrm{Np}(\mathrm{IV})$. Therefore, this experiment is not able to provide quantitative information on surface $\mathrm{Np}$ redox speciation, because it might underestimate the amount of $\mathrm{Np}(\mathrm{IV})$. It is, however, sufficient to demonstrate that a significant amount of $\mathrm{Np}(\mathrm{IV})$ is present at the illite surface.

\subsection{Redox conditions}

The $\mathrm{pH}-\mathrm{pe}(\mathrm{Eh})$ diagram for $\mathrm{Np}$ in $0.1 \mathrm{M} \mathrm{NaCl}$ is shown in figure 5 . The measured $\mathrm{pH}$ pe values are presented for the batch experiments performed at relatively low $[\mathrm{Np}]_{\text {tot }}$ (black squares) and two samples at relatively high $[\mathrm{Np}]_{\text {tot }}\left(3 \times 10^{-4} \mathrm{M}\right.$, large white circles $)$ prepared for analysis with spectroscopic techniques. Redox borderlines for all experiments are included, as well, by considering the possible precipitation of $\mathrm{Np}(\mathrm{IV})$-(hydr)oxide $\left(\mathrm{NpO}_{2(\mathrm{am})}\right)$ at total $\mathrm{Np}$

concentrations of $3 \times 10^{-8} \mathrm{M}$ and $3 \times 10^{-4} \mathrm{M}$, respectively. "Redox neutral" conditions are also shown for comparison $(\mathrm{pH}+\mathrm{pe}=13.8$; see e.g. Neck et al. (2007) for more details). For low $\mathrm{Np}$ concentrations all experiments are clearly located in the predominance field of $\mathrm{Np}(\mathrm{V})$, as also observed by the redox state analysis of $\mathrm{Np}$ in the supernatant. Those data at a first glance cannot justify the hypothesis of $\mathrm{Np}(\mathrm{V})$ reduction in presence of Na-illite. At high $\mathrm{Np}$ concentrations, however,pe data hit the redox borderline, suggesting the establishment of an equilibrium with solid $\mathrm{Np}(\mathrm{IV}) \mathrm{O}_{2(\mathrm{am})}$ and $\mathrm{Np}(\mathrm{V})$ species in solution.Note that surface sorptionequilibria are not taken into account for those scoping calculations.

\subsection{Spectroscopic results}


$\mathrm{Np}$ redox speciation at the illite surface is further investigated by XANES. The $\mathrm{Np} \mathrm{L}_{3}-$ XANES measured at $\mathrm{pH}=7.4, \mathrm{~m} / \mathrm{V}=20 \mathrm{~g} / \mathrm{L}$ and $3 \times 10^{-4} \mathrm{M}$ of $\mathrm{Np}$ (initially introduced as $\mathrm{NpO}_{2}{ }^{+}$) is presented on figure $6 \mathrm{a}$. This sample contains the highest $[\mathrm{Np}]_{\text {tot }}$ and exhibits as well the highest pe (pe $=6.8 \pm 0.8$ ). Under those conditions $15 \%$ of the total $\mathrm{Np}$ is sorbed onto illite (i.e. $2.3 \times 10^{-3} \mathrm{~mol} / \mathrm{kg}$ ). As explained before, phase separation was performed to remove the solution from the sample. Therefore, the following analysis will refer only to the amount on $\mathrm{Np}$ present in the solid phase (i.e. $15 \%$ of the initially introduced $\mathrm{Np}$ ). The presence of a shoulder at $17625 \mathrm{eV}$, indicating multiple scattering of the outgoing $\mathrm{Np} 2 \mathrm{p}_{3 / 2}$ electron along the axis of the $\mathrm{NpO}_{2}{ }^{+}$dioxo cation, shows the dominance of the $+\mathrm{V}$ redox state. However, the "white line" (WL) position as well as the inflection point of $\mathrm{Np}$ redox states $+\mathrm{IV}$ and $+\mathrm{V}$ is relatively similar and cannot be used as a conclusive probe for $\mathrm{Np}$ redox speciation. Nevertheless, $\mathrm{Np}(\mathrm{V})$ and $\mathrm{Np}(\mathrm{IV})$ XANES show significant differences in the intensity of the WL. Previously published XANES, measured at the same beam line, were selected for this purpose. XANES spectra of the $\mathrm{NpO}_{2}^{+}$and $\mathrm{Np}^{4+}$ aquo ions in $0.1 \mathrm{M} \mathrm{HClO}_{4}$ from Gaona et al. (2012) are used as references for $\mathrm{Np}(\mathrm{V})$ and $\mathrm{Np}(\mathrm{IV})$. When plotted together, the Np-illite XANES for $\mathrm{pH}=7.4$ shows significant differences compared to a $\mathrm{Np}(\mathrm{V})$ reference, especially an increase in WL intensity (fig. 6). The same energy range is considered for the pre-edge and for the normalization of all XANES spectra (pre-edge: 17.30-17.55 keV; post-edge: 17.77$18.20 \mathrm{keV}$ ) and careful preliminary tests were made to ensure that the observed differences in the XANES are not due to the normalization procedure. Additionally, a decrease at $\sim 17635$ and an increase at $\sim 17660 \mathrm{eV}$ are observed. These two observations are consistent with the presence of a mixture of $\mathrm{Np}(\mathrm{V})$ and $\mathrm{Np}(\mathrm{IV})$.

As pointed out by Denecke et al. (2005), the determination of Np redox speciation by XANES analysis can be difficult under certain conditions. In their study, a sample containing $\mathrm{Np}(\mathrm{IV})$ was partially oxidized to $\mathrm{Np}(\mathrm{V})$, leading to a decrease in WL intensity. Because the 
white line height decreases substantially going from ions in solution to solids (condensed system), it could have been erroneously attributed to the formation of $\mathrm{Np}(\mathrm{IV})$-(hydr)oxides, if the composition of the sample had been unknown. In the present study, the situation is different. The WL of $\mathrm{Np}(\mathrm{V})$ sorbed to a mineral surface cannot be more intense than that of $\mathrm{Np}(\mathrm{V})$ aquo-ion. Therefore, the present results can confidently be attributed to the presence of $\mathrm{Np}(\mathrm{IV})$. By fitting the $\mathrm{Np}$-illite XANES with a linear combination of $\mathrm{Np}(\mathrm{V})$ and $\mathrm{Np}(\mathrm{IV})$ reference samples, $14 \%$ of the adsorbed $\mathrm{Np}$ is determined to be $\mathrm{Np}(\mathrm{IV})$. The result of the linear combination fit(LCF) is shown in figure S4. Although this value is small, it must be considered as a minimum value since the aquo-ions exhibit the most intense WLs. The same exercise with either a $\mathrm{Np}(\mathrm{V})$ or a $\mathrm{Np}(\mathrm{IV})$ reference, where $\mathrm{Np}$ is in a more condensed state (i.e. with a less intense WL), would lead to a larger fraction of $\mathrm{Np}(\mathrm{IV})$. No further attempt was made to accurately determine the amount of $\mathrm{Np}(\mathrm{IV})$, and the spectroscopic result is taken to corroborate the redox state analysis by liquid-liquid extraction showing that $\mathrm{Np}(\mathrm{V})$ reduction to $\mathrm{Np}(\mathrm{IV})$ can occur in the presence of illite.

An additional sample is analyzed by XANES under similar initial conditions but at $\mathrm{pH}$ = 9.6. The measured pe does not significantly differ from that obtained at $\mathrm{pH}=7.4$ (pe $=6.8 \pm$ 0.8).Invariant pe at higher $\mathrm{pH}$ implies more oxidizing conditions in this additional sample. Due to the higher $\mathrm{pH}, 90 \%$ of $\mathrm{Np}$ is sorbed to the illite surface $\left(1.3 \times 10^{-2} \mathrm{~mol} / \mathrm{kg}\right)$, which can be partly attributed to the stronger surface complexation of $\mathrm{Np}(\mathrm{V})$ to illite (Gorgeon, 1994) at this $\mathrm{pH}$. The $\mathrm{Np} \mathrm{L}_{3}$-XANES of the sample for $\mathrm{pH}=9.6$ is also shown in Figure 6. It shows a less intense WL compared to $\mathrm{pH}=7.4$. The LCF using the XANES spectra of $\mathrm{NpO}_{2}^{+}$and $\mathrm{Np}^{4+}$ aquo-ion shows that only $5 \%$ of the adsorbed $\mathrm{Np}$ at the illite surface is $\mathrm{Np}$ (IV) (fig. S4). Given the uncertainty of the measured pe, the stability of a fraction of $\mathrm{Np}(\mathrm{IV})$ in the present samples is also qualitatively in agreement with thermodynamic calculations, considering the formation of $\mathrm{NpO}_{2(\mathrm{am})}$ (fig. 5). 


\subsection{Surface complexation modeling}

The aim of the present section is to attempt a complete description of $\mathrm{Np}$ sorption and concomitant redox reactions in presence of illite as a function of $\mathrm{pH}$, pe and $[\mathrm{Np}]_{\text {tot }}$. Assuming that the Np-illite system in each sample is in equilibrium, the data might be simulated by taking into account constants for the respective redox, complexation and surface sorption reactions.

Surface complexation calculations are made with the 2 SPNE SC/CE model. We only consider strong sites at the illite surface and thus constrain the modeling exercise to experimental data obtained at total $\mathrm{Np}$ concentrations up to $10^{-6} \mathrm{M}$. Only the sorption data with experimentally determined pe are considered because pe is necessary to calculate $\mathrm{Np}$ redox speciation according to the first equation in table 1 . We furthermore take surface complexation constants and selectivity coefficients (Bradbury and Baeyens, 2009b) derived from Gorgeon's data obtained under aerobic conditions to describe sorption of $\mathrm{Np}(\mathrm{V})$ species. Cation exchange reactions are not considered for $\mathrm{Np}(\mathrm{IV})$ species as they are assumed irrelevant for tetravalent metal ions (Bradbury and Baeyens, 2009b).Np(IV)-illite surface complexation constants values estimated from the LFER (eq. 4) are taken as starting points and fitted to the experimental $\log \mathrm{R}_{\mathrm{d}}$ data using PhreePlot. According to the $2 \mathrm{SPNE} \mathrm{SC} / \mathrm{CE}$ model for the sorption of Th(IV) (Bradbury and Baeyens, 2009b), $\equiv \mathrm{SO}-\mathrm{Np}(\mathrm{OH})_{4}{ }^{-}$is expected to be the dominant $\mathrm{Np}(\mathrm{IV})$ surface species at least for $\mathrm{pH}>7$.An approximation for the respective surface complexation constant by LFER was not possible because it requires a complexation constant for $\mathrm{Np}(\mathrm{OH})_{5}{ }^{-}$, for which no value has been selected in the NEA database (Guillaumont et al., 2003). We, therefore, took literature data for the $\equiv \mathrm{SO}-\mathrm{Th}(\mathrm{OH})_{4}{ }^{-}$ complex as an initial value for the fitting. Note that additional sensitivity tests showed that the fitting procedure converged to very similar constants independent of the initial values. As a 
result, we obtained values for surface complexation constants for $\mathrm{Np}(\mathrm{IV})$ as given in table 1 . Values estimated by applying the LFER are given in brackets and are very similar to the fit results. The uncertainties for respective $\log \mathrm{K}$ values are composed of contributions arising from (i) the statistical uncertainty associated with the fitting procedure, calculated by PhreePlot (between 0.1 and $0.2 \log$ units), (ii) the experimental error inpe (i.e. \pm 0.8 ) and (iii) the experimental error in $\log \mathrm{R}_{\mathrm{d}}$ (i.e. \pm 0.3 ). The results are presented in Figure 7 for the complete dataset used to fit the surface complexation constants for $\mathrm{Np}(\mathrm{IV})$. Figures $7 \mathrm{a}, 7 \mathrm{~b}$ and $7 \mathrm{c}$ show $\log \mathrm{R}_{\mathrm{d}}$ versus $\mathrm{pH}$ for the three series of experiments with $[\mathrm{Np}]_{\mathrm{tot}}=10^{-6}, 10^{-7}$ and $3 \times 10^{-}$ ${ }^{8} \mathrm{M}$, respectively. Experimental $\log \mathrm{R}_{\mathrm{d}}$ and the corresponding calculated values with the fitted constants are shown, respectively, as black and white symbols. Figures $7 \mathrm{c}, 7 \mathrm{~d}$ and $7 \mathrm{e}$ show the corresponding redox conditions for each series on a pH-pe(Eh) diagram. In addition, calculations with constant redox conditions (i.e. constant $\mathrm{pH}+\mathrm{pe}$ values) for each series in the range of the expected experimental uncertainty (i.e. \pm 0.8 pe units $/ \pm 50 \mathrm{mV}$ ) illustrate the coupled effect of $\mathrm{pH}$ and pe on $\mathrm{Np}$ sorption to illite. The increase of $\log \mathrm{R}_{\mathrm{d}}$ with decreasing $[\mathrm{Np}]_{\text {tot }}$ is well described. Actually, this behavior is directly related to the redox conditions: on average $\mathrm{pH}+\mathrm{pe}$ decreases from 12.5 to 11.5 with $[\mathrm{Np}]_{\text {tot }}$ decreasing from $10^{-6}$ to $3 \times 10^{-8} \mathrm{M}$. Calculated sorption of $\mathrm{Np}$ to illite is very sensitive to the pe. This can be seen (i) in the simulations, where \pm 0.8 pe units leads to important variations in $\log \mathrm{R}_{\mathrm{d}}$ for a given $\mathrm{pH}$ value and (ii) in the results of the fit, where scattering in the experimentally determined pe also leads to scattering in the $\log \mathrm{R}_{\mathrm{d}}$ values. The latter observation might explain why our $\mathrm{Np}$ sorption results seem to exhibit larger uncertainty than commonly assumed (i.e. $\pm 0.3 \log R_{d}$ units). Additionally, the results of the fit are shown for $\mathrm{pH}=7.2 \pm 0.2$ and as a plot of calculated versus experimental $\log \mathrm{R}_{\mathrm{d}}$ for the complete dataset (i.e. for the various $\mathrm{pH}$, pe, contact time, and $[\mathrm{Np}]_{\text {tot }}$ ) in figure S5. Average differences between calculated and experimental $\log \mathrm{R}_{\mathrm{d}}$ data (based on the RMSD) is found equal to 0.36, which lies in the same range as experimental uncertainties. Speciation calculations furthermore give no evidence for 
the precipitation of $\mathrm{NpO}_{2(\mathrm{am})}$ under any investigated condition. Due to the predominance of $\mathrm{Np}(\mathrm{V})$ in solution and the strong surface complexation of $\mathrm{Np}(\mathrm{IV})$ to illite, aqueous $\mathrm{Np}(\mathrm{IV})$ concentrations remain below solubility limits with regard to $\mathrm{NpO}_{2(\mathrm{am})}$.

In order to check the reliability of the fitted $\log \mathrm{K}$ value for the $\equiv \mathrm{SO}-\mathrm{Np}(\mathrm{OH})_{4}{ }^{-}$surface complex, we performed predictive simulations of $\mathrm{Np}(\mathrm{IV})$ sorption to illite (log $\mathrm{R}_{\mathrm{d}} \mathrm{vs} \mathrm{pH}$ ) using the constant in table 1 . Those calculated data are then compared with experimental data for $\mathrm{Sn}(\mathrm{IV})$ and Th(IV) taken from the literature (Bradbury and Baeyens, 2009a,b) (figure 8). Experimental $\mathrm{R}_{\mathrm{d}}$ values for both tetravalent metal ions are very similar and invariant in the $\mathrm{pH}$ range from 3 to 11.Taking the relatively large confidence interval into account simulated log $R_{d}$ values for $\mathrm{Np}(\mathrm{IV})$ and $\mathrm{Sn}(\mathrm{IV}), \mathrm{Th}(\mathrm{IV})$ are quite consistent. Note that the surface complexation constants for $\mathrm{Np}(\mathrm{IV})$ (Table 1) are larger than previously reported for $\mathrm{Th}(\mathrm{IV})$ (Bradbury and Baeyens, 2009b). This observation is consistent with the stronger hydrolysis of $\mathrm{Np}(\mathrm{IV})$ than Th(IV) according to the LFER of Bradbury and Baeyens (2009b).

\section{6. $\mathrm{Np}(\mathrm{V}) / \mathrm{Np}(\mathrm{IV})$ redox speciation in presence of illite}

Based on constants given in table 1, PhreePlot was used to construct a predominance diagram for $\mathrm{Np}$ surface speciation for the range $4<\mathrm{pH}<10$ (figure 9; grey lines). The pe-pH diagram is superimposed by the respective predominance diagram for aqueous species (figure 9; black lines). When $\mathrm{Np}(\mathrm{V})$ sorption is weak, being controlled either by cation exchange or weak surface complexation (i.e. for $\mathrm{pH}<8$ ), reduction to $\mathrm{Np}(\mathrm{IV}$ ) at the surface is thermodynamically highly favored due to the strong sorption of $\mathrm{Np}(\mathrm{IV})$ even at relatively high pe. The redox boundary for the $\mathrm{Np}(\mathrm{V}) / \mathrm{Np}(\mathrm{IV})$ couple for illite surface bound species is by approximately $4.6-5$ pe units $(0.27-0.30 \mathrm{~V})$ higher than for the corresponding dissolved species at $\mathrm{pH}<8$. For $\mathrm{pH}>8, \mathrm{~Np}(\mathrm{~V})$ surface complexation to illite edge sites increases, via the formation of $\equiv \mathrm{SO}-\mathrm{NpO}_{2} \mathrm{OH}^{-}$species according to the 2 SPNE SC/CE model. Consequently, reduction to $\mathrm{Np}(\mathrm{IV})$ at the illite surface becomes less favorable and the redox boundary 
surface species is only approximately 3 pe units $(0.18 \mathrm{~V})$ higher as compared to the respective solute species at $\mathrm{pH}=10$. Hixon et al. (2013) observed surface mediated reduction of $\mathrm{Pu}(\mathrm{V})$ to $\mathrm{Pu}(\mathrm{IV})$ in the presence of quartz. Based on the thermodynamic favorability of $\mathrm{Pu}(\mathrm{IV})$ at the quartz surface, the authors calculated that the redox potential of the $\mathrm{Pu}(\mathrm{V}) / \mathrm{Pu}(\mathrm{IV})$ couple would need to be raised by $0.28 \mathrm{~V}$ for $\mathrm{pH}=7$. Remarkably, although the study of Hixon et al. (2013) involves another actinide and another mineral than in this study, these independent estimations are in very good agreement.

pe-pH data plotted for all experiments in figure 9 reveal that despite the fact that they all lie within the predominance field of aqueous $\mathrm{Np}(\mathrm{V})$ species, reduction to $\mathrm{Np}(\mathrm{IV})$ becomes thermodynamically favored in the presence of illite. In turn, we can explain the high $\mathrm{R}_{\mathrm{d}}$ values measured under our experimental conditions due to strong sorption of $\mathrm{Np}(\mathrm{IV})$ species at the illite surface being in equilibrium with $\mathrm{Np}(\mathrm{V})$ species in solution.

The situation is somewhat different for the two samples prepared for spectroscopic studies and containing total $\mathrm{Np}$ concentrations as high as $3 \times 10^{-4} \mathrm{M} \mathrm{Np}$. Thus the amount of $\mathrm{Np}$ sorbed to illite exceeds the strong sites surface density $\left(4 \times 10^{-5} \mathrm{~mol} / \mathrm{L}\right.$ at $\left.\mathrm{m} / \mathrm{V}=20 \mathrm{~g} / \mathrm{L}\right)$. Based on data given in table 1, calculations indicate partial formation of $\mathrm{NpO}_{2(\mathrm{am})}$. However, sorption of $\mathrm{Np}(\mathrm{IV})$ to weak sites being present in high excess $\left(8 \times 10^{-4} \mathrm{~mol} / \mathrm{L}\right)$ is also very likely. Unfortunately, data for the sorption of $\mathrm{Np}(\mathrm{V})$ and $\mathrm{Np}(\mathrm{IV})$ to illite weak sites are not available from the literature and cannot be derived from our experiments. It should be noted that weak site complexation for actinide ions is not very relevant for environmental purposes related to nuclear waste disposal. We, therefore, cannot decide at present based on available geochemical data, whether $\mathrm{Np}(\mathrm{IV})$ in those samples exists primarily as surface complex or at least partially as well asNpO 2 (am).

As mentioned before, experiments have been performed under Ar atmosphere. In absence of oxidizing or reducing agents experimentally determined pe-pH values should thus 
follow the "redox neutral" line where $(\mathrm{pe}+\mathrm{pH})=13.8$ (dashed line in fig. 9) (Neck et al., 2007). Apparently, our data lie below this line, i.e. a reductant must be active in the system. $\mathrm{Fe}(\mathrm{II})$ is known as an efficient redox partner, inducing reduction of different elements in the presence of minerals within hours or days (Bruege et and Hug, 1999; Liger et al., 1999; Nakata et al., 2002; Powell et al., 2004; Charlet et al., 2007; Chakraborty et al., 2010; Bach et al., 2014). It has been previously shown that both structural and adsorbed Fe(II) in clay systems can reduce U(VI) to U(IV) (Chakraborty et al., 2010; Latta et al., 2012). Although the illite sample investigated in our studies was purified under aerobic conditions, the presence of traces of structural $\mathrm{Fe}(\mathrm{II})$ or adsorbed $\mathrm{Fe}(\mathrm{II})$, possibly formed via partial dissolution of the clay under anaerobic conditions, cannot be ruled out. Moreover, $\mathrm{Np}(\mathrm{V})$ reduction by dissolved Fe(II) in homogeneous solution was shown to be slow (Nakata et al., 2002): only $6 \%$ of $\mathrm{Np}(\mathrm{IV})$ was formed at $\mathrm{pH}=4$ or 6 after one week. Therefore, a surface mediated reduction of $\mathrm{Np}(\mathrm{V})$ to $\mathrm{Np}(\mathrm{IV})$ by $\mathrm{Fe}(\mathrm{II})$ contained in the illite certainly represents one possibility. In this case reduction could be achieved by electron transfer from the bulk to the illite surface (e.g. Schaefer et al., 2011). Another option is reduction by adsorbed Fe(II) (see e.g. Chakraborty et al., 2010). A spectroscopic identification of Fe(II) in our experimental system, however, appears to be hardly possible. A maximum of $6.8 \times 10^{-4} \mathrm{~mol} \mathrm{~Np} / \mathrm{kg}$ illite was found to be reduced $\mathrm{Np}(\mathrm{IV})$. The corresponding amount of $\mathrm{Fe}(\mathrm{II})$ required for $\mathrm{Np}(\mathrm{V})$ reduction then corresponds to about $0.08 \%$ of the total amount of Fe contained in the illite (7wt. $\%$ as $\mathrm{Fe}_{2} \mathrm{O}_{3}$ gives $0.88 \mathrm{~mol}$ of Fe per kg of illite). Such small fractions are very likely below the detection limit of available experimental techniques. The fact that experimental pe values are to some extent affected by the total amount of initially introduced $\mathrm{NpO}_{2}{ }^{+}$(see section 3.2) also suggests that the total reducing capacity in our system is low. Due to those uncertainties we are presently unable to determine precisely the nature of the redox reaction on a molecular scale. Nevertheless, the finding that sorption data can be consistently described using pe values as relevant master parameter clearly demonstrates the applicability of the 
thermodynamic equilibrium approach to simulate coupled redox sorption processes in clay mineral systems.

\section{CONCLUSIONS}

The unusually high $\mathrm{Np}(\mathrm{V})$ sorption to illite observed in the present study can be explained by partial reduction and concomitant formation of stable surface $\mathrm{Np}(\mathrm{IV})$ species. We found a clear relationship of measured pe with $R_{d}$ values: $\mathrm{Np}$ sorption increases with decreasing redox potential. Our combined batch sorption, spectroscopic and geochemical modeling study suggests that the predominance field of reduced $\mathrm{Np}(\mathrm{IV})$ species in a pe-pH diagram expands significantly due to the thermodynamically favored formation of $\mathrm{Np}(\mathrm{IV})$ surface complexes in a wide $\mathrm{pH}$ range. The retention of redox sensitive $\mathrm{Np}$ species is thus much more efficient under pe conditions only slightly below redox neutrality in presence of mineral surfaces than expected. Scoping geochemical estimations of radionuclide redox states at given pe and $\mathrm{pH}$ values but neglecting surface complexation reactions can thus be misleading. The result that measured pe values can be taken as a master parameter to simulate complex redox processes including surface reactions is encouraging, even though the determination of redox potentials is flawed by relatively high analytical uncertainties. Nevertheless, by using the measured pe as an input parameter, $\mathrm{Np}(\mathrm{IV})$ surface complexation constants for the 2 SPNE SC/CE model could be fitted to the experimental data which are very comparable to those values estimated by applying an established LFER approach. The complete sorption dataset can be numerically described assuming surface mediated reduction of $N p(V)$ to $N p(I V)$ based on the strong affinity of $N p(I V)$ for the illite surface.

The exact mechanism of $\mathrm{Np}(\mathrm{V})$ reduction, however, could not be clarified within the present study due to the apparently limited concentration of reductant species. The fact that redox and sorption equilibria establish relatively fast, points to a surface mediated process. Electron transfer from adsorbed or structurally bound $\mathrm{Fe}(\mathrm{II})$ to surface bound $\mathrm{Np}(\mathrm{V})$ is 
considered a plausible mechanism for the observed coupled redox/sorption reaction. The presented modeling approach, however, predicts reduction also in absence of an explicit reductant in the solid. The thermodynamical stability of $\mathrm{Np}(\mathrm{IV})$ surface species alone is sufficient to shift the redox borderline and to induce partial $\mathrm{Np}(\mathrm{V})$ reduction.

The presented modeling concept might be applicable as well to describe the behavior of other redox-sensitive elements in the geosphere.

\section{ACKNOWLEDGEMENTS}

We gratefully acknowledge Ms. Bender for laboratory work and analytical support. This work was partially financed by The Federal Ministry of Economics and Technology (Germany) under Contract No. 02E10206. The research leading to these results has received funding from the European Union's European Atomic Energy Community's (Euratom) Seventh Framework Program FP7/2007-2011 under grant agreement n 249624 (CATCLAY project).

\section{Supporting Information Available}

Additional material is provided in the supporting information section.

\section{REFERENCES}

Altmaier M., Gaona X. and Fanghänel T. (2013) Recent Advances in Aqueous Actinide Chemistry and Thermodynamics. Chem. Rev.113, 901-943.

Altmaier M., Gaona X., Fellhauer D. and Buckau G. (2010) Intercomparison of redox determination methods on designed and near-neutral aqueous systems. KIT-SR 7572, Karlsruhe Institute of Technology, Karlsruhe.

Amayri S., Jermolajev A. and Reich T. (2011) Neptunium(V) sorption on kaolinite, Radiochim. Acta.99, 349-357. 
Bach D., Christiansen B. C., Schild D. and Geckeis H. (2014) TEM study of Green Rust Sodium Sulphate $\left(\mathrm{GR}_{\mathrm{Na}, \mathrm{SO} 4}\right)$ Interacted with Neptunyl Ions $\left(\mathrm{NpO}_{2}^{+}\right)$. Radiochim. Acta102(4), 279-290.

Bertrand P. A and Choppin G. R. (1982) Separation of Actinides in Different OxidationStates by Solvent Extraction. Radiochim. Acta31, 135-137.

Bradbury M.H. and Baeyens B. (2005) Experimental and modelling investigations on Naillite: acid-base behaviour and the sorption of strontium, nickel, europium and uranyl: PSI Bericht Nr. 05-02 Paul ScherrerInstitut, Villigen, Switzerland and Nagra NTB 0402, Nagra, Wettingen, Switzerland.

Bradbury M.H. and Baeyens B. (2006) Modelling sorption data for the actinides Am(III), $\mathrm{Np}(\mathrm{V})$ and $\mathrm{Pa}(\mathrm{V})$ on montmorillonite. Radiochim. Acta94, 619-625.

Bradbury M.H. and Baeyens B. (2009a) Sorption modelling on illite Part I: Titration measurements and the sorption of Ni, Co, Eu and Sn. Geochim. Cosmochim. Acta.73, 990-1003.

Bradbury M.H. and Baeyens B. (2009b) Sorption modeling on illite Part II: actinide sorption and linear free energy relationships. Geochim. Cosmochim. Acta.73, 1004-1013.

Brendebach B., Banik N. L., Marquardt C. M., Rothe J., Denecke M. and Geckeis H. (2009) $\mathrm{X}$ - ray absorption spectroscopic study of trivalent and tetravalent actinides in solution at varying $\mathrm{pH}$ value. Radiochim. Acta97, 701-708.

Buerge I. J. and Hug S. J. (1999) Influence of mineral surfaces on chromium(VI) reduction by iron(II). Environ. Sci. Technol.33, 4285-4291.

Chakraborty S., Favre F., Banerjee D., Scheinost A. C., Mullet M., Ehrhardt J.-J., Brendle J., Vidal L. and Charlet L. (2010) U(VI) Sorption and Reduction by Fe(II) Sorbed on Montmorillonite. Environ. Sci. Technol.44 (10), 3779-3785.

Charlet L., Scheinost A. C., Tournassat C., Greneche J. M., Géhin A., Fernandez-Martinez A., Coudert S., Tisserand D. and Brendle J. (2007) Electron transfer at the mineral/water interface: Selenium reduction by ferrous iron sorbed on clay. Geochim. Cosmochim. Acta71, 5731-5749.

Claret F.,Schäfer T., Rabung T., Wolf M., Bauer A. and Buckau G. (2005) Differences in properties and $\mathrm{Cm}(\mathrm{III})$ complexation behavior of isolated humic and fulvic acid derived from Opalinus clay and Callovo-Oxfordian argillite.Appl.Geochem. 20, 11581168 .

Degueldre C. and Bolek M. (2009) Modelling colloid association with plutonium: The effect of $\mathrm{pH}$ and redox potential. Appl.Geochem.24, 310-318.

Denecke M. A., Dardenne K. and Marquardt C. M. (2005) Np(IV)/ $\mathrm{Np}(\mathrm{V})$ valence determinations from Np L3 edge XANES/EXAFS. Talanta65, 1008-1014.

Freundlich H. (1909) Kapillarchemie. AkademischeVerlagsgesellschaft, Leipzig, Germany.

Fröhlich D. R., Amayri S., Drebert J. and Reich T. (2011) Sorption of neptunium(V) on Opalinus Clay under aerobic/anaerobic conditions. Radiochim. Acta99, 71-77. 
Fröhlich D. R., Amayri S., Drebert J., Grolimund D., Huth J., Kaplan U., Krause J. and Reich T. (2012) Speciation of $\mathrm{Np}(\mathrm{V})$ uptake by Opalinus Clay using synchrotron microbeam techniques.Anal. Bioanal. Chem.404, 2151-2162.

Gabis V. (1963) Etude mineralogique et geochimique de la seriesedimentaireoligocene du Velay. Bulletin SocieteFrancaise de Mineralogie et Cristallographie86, 315-354.

Gaona X., Tits J., Dardenne K., Liu X., Rothe J., Denecke M. A., Wieland E. and Altmaier M. (2012) Spectroscopic investigations of $\mathrm{Np}(\mathrm{V} / \mathrm{VI})$ redox speciation in hyperalkaline TMA- $(\mathrm{OH}, \mathrm{Cl})$ solutions. Radiochim. Acta100, 759-770.

Geckeis H., Lützenkirchen J., Polly R., Rabung T. and Schmidt M. (2013) Mineral-Water Interface Reactions of Actinides. Chem. Rev.13 (2), 1016-1062.

Gorgeon L. (1994) Contribution à la modélisation physico-chimique de la rétention de radioéléments à vie longue par des matériaux argileux. Ph.D. thesis, Université Paris 6.

Guillaumont R., Fanghänel Th., Fuger J., Grenthe I., Neck V., Palmer D.A. and Rand M.H. (2003) Update on the Chemical Thermodynamics of Uranium, Neptunium, Plutonium, Americium and Technetium, Mompean, F.J., Domenech-Orti, C., Ben-Said, K., OECD/NEA Data Bank, Eds., vol. 5 of Chemical Thermody-namics, Elsevier, Amsterdam.

Hixon A. E., Arai Y. and Powell B. A. (2013) Examination of the effect of alpha radiolysis on plutonium(V) sorption to quartz using multiple plutonium isotopes. J. Coll. Int. Sci.403, 105-112.

Hixon A. E., Hu Y.-J., Kaplan D.I., Kukkadapu R.K., Nitsche H., Qafoku O. and Powell B. A. (2010) Influence of iron redox transformations on plutonium sorption to sediments. Radiochim. Acta98, 685-692.

Kim J. I. (1986) Chemical behaviour of transuranic elements in natural aquatic systems. In: Handbook on the Physics and Chemistry of the Actinides. (Freeman, A. J., ed.) Elsevier Science Publishers, B. V., Amsterdam p. 413.

Kinniburgh D.G. and Cooper D.M. (2009) PhreePlot: Creating graphical output with PHREEQC. <http://www.phreeplot.org >.

Kirsch R., Fellhouer D., Altmaier M., Neck V., Rossberg A., Fanghänel T., Charlet L. and Scheinost A. C. (2011) Oxidation State and Local Structure of Plutonium Reacted with Magnetite, Mackinawite, and Chukanovite. Environ. Sci. Technol.45, 7267-7274

Latrille C., Ly J. and Herbette M. (2006) Retention of Sn(IV) and Pu(IV) onto four argillites from the Callovo-Oxfordian level at Bure (France) from eight equilibrated sedimentary waters. Radiochim. Acta.94, 421-427.

Latta D. E., Boyanov M. I., Kemner K. M., O’Loughlin E.J. and Scherer M. M. (2012) Abiotic reduction of uranium by Fe(II) in soil. Appl.Geochem.27, 1512-1524.

Liger L., Charlet L. and Van Cappellen P. (1999) Surface catalysis of uranium(VI) reduction by iron(II). Geochim. Cosmochim. Acta63, 2939-2955.

Marques-Fernandes M., Baeyens B, Dähn R., Scheinost A.C. and Bradbury M.H. (2012) $\mathrm{U}(\mathrm{VI})$ sorption on montmorillonite in the absence and presence of carbonate: A macroscopic and microscopic study. Geochim. Cosmochim. Acta93, 262-277. 
Nakata K., Nagasaki S., Tanaka S., Sakamoto Y., Tanaka and Ogawa H. (2002) Sorption and reduction of neptunium(V) on the surface of iron oxides. Radiochim. Acta90, 665-669.

Neck V., Altmaier M. and Fanghänel T. (2007) Solubility of plutonium hydroxides/hydrous oxides under reducing conditions and in the presence of oxygen. C. R. Chimie10, 959977

Nitsche H, Lee S. C and Gatti R. C. (1988) Determination of Plutonium Oxidation States at Trace Levels Pertinent to Nuclear Waste Disposal. J. Radioanal. Nucl. Chem.124, 171185 .

Nitsche H., Roberts K., Xi R., Prussin T., Becraft K., Mahamid I. A., Silber H. B., Carpenter S. A. and Gatti R. C. (1994) Long term plutonium solubility and speciation studies in a synthetic brine. Radiochim. Acta.66, 3-7.

Parkhurst D.L. and Appelo C.A.J. (1999) User's guide to PHREEQC (Version 2) - a computer program for speciation, batch reaction, one-dimensional transport and inverse geochemical calculation. Water-resources Investigation Report 99-4259, USGS, Denver, Colorado, p. 312.

Poinssot C., Baeyens B. and Bradbury M. H. (1999). Experimental Studies of Cs, Sr, Ni and Eu Sorption on Na-Illite and the Modelling of Cs Sorption. PSI Bericht Nr. 99-06. Paul ScherrerInstitut, Villigen and Nagra Technical Report NTB 99-04, Nagra, Wettingen, Switzerland.

Powell B. A., Fjeld R. A., Kaplan D. I., Coates J. T. and Serkiz S. M. (2004) $\mathrm{Pu}(\mathrm{V}) \mathrm{O}_{2}{ }^{+}$ adsorption and reduction by synthetic magnetite $\left(\mathrm{Fe}_{3} \mathrm{O}_{4}\right)$. Environ. Sci. Technol.38, 6016.

Powell B. A., Fjeld R. A., Kaplan D. I., Coates J. T. and Serkiz S. M. (2005) Pu(V) $\mathrm{O}_{2}^{+}$ adsorption and reduction by synthetic hematite and goethite. Environ. Sci. Technol.39, 2107.

Powell M.J.D. (1965) A method for minimizing a sum of squares of non-linear functions without calculating derivatives. The Computer Journal7, 303-307.

Ravel B. and Newville M. (2005) ATHENA and ARTEMIS: data analysis for X-ray absorption spectroscopy using IFEFFIT. Journal of Synchrotron Radiation12, 537-541.

Rothe J., Butorin S., Dardenne K., Denecke M. A., Kienzler B., Löble M., Metz V., Seibert A., Steppert M., Vitova T., Walther C. and Geckeis H. (2012) The INE-Beamline for actinide science at ANKA. Rev. Sci. Instrum.83, 043105.

Rothe J., Denecke M. A., Dardenne K. and Fanghänel T. (2006) The INE- beamline for actinide research at ANKA. Radiochim. Acta.94, 691.

Schaefer M., Gorski C. A. and Scherer M.M. (2011) Spectroscopic Evidence for Interfacial $\mathrm{Fe}(\mathrm{II})-\mathrm{Fe}(\mathrm{III})$ Electron Transfer in a Clay Mineral. Environ. Sci. Technol.45, 540-545.

Schüring J., Schulz H. D., Fischer W. R., Böttcher J. and Duijnisveld W. H. M. (2000) Redox: fundamentals, processes and applications. Springer-Verlag Berlin Heidelberg New York. $251 \mathrm{p}$. 
Schwantes J. M. and Santschi P. H. (2010) Mechanisms of plutonium sorption to mineral oxide surfaces: new insights with implications for colloid-enhanced migration. Radiochim. Acta98, 737-742.

Sjoblom R. and Hindman J.C. (1951) Spectrophotometry of Neptunium in Perchloric Acid Solutions. J. Am. Chem. Soc.73(4), 1744-1751.

Stumm W. (1992) Chemistry of the solid-water interface. Wiley-Interscience, New York.

Turner D. R., Pabalan R. T. and Bertetti F. P. (1998) Neptunium(V) sorption on montmorillonite: An experimental and surface complexation modeling study. Clays Clay Miner. 46, 256.

Wu T., Amayri S., Drebert J., Van Loon L.R. and Reich T. (2009) Neptunium(V) sorption and diffusion in Opalinus clay. Environ. Sci. Technol.43, 6567-6571.

Zaravin M., Powell B. A., Bourbin M., Pihong Zhao P. and Kersting A. B. (2012) $\mathrm{NpO}_{2}{ }^{+}$ and $\mathrm{Pu}(\mathrm{V})$ ion exchange and surface-mediated reduction mechanisms on montmorillonite, Environ. Sci. Technol.46, 2692-2698. 


\section{Table and figure captions:}

Table 1. Reactions and respective thermodynamic constants used in the present modeling section. Aqueous reaction constants and the solubility product of $\mathrm{NpO}_{2(\mathrm{am})}$ are taken from Guillaumont et al. (2003). The missing $\mathrm{Np}(\mathrm{OH})_{3}{ }^{+}$formation constant is taken from the analogue $\mathrm{Pu}(\mathrm{OH})_{3}{ }^{+}$."f" denotes fixed parameters during the fitting procedure, taken for Bradbury and Baeyens (2009). Np(IV) surface complexation constants are fitted from the present experimental results associated with their uncertainty. Calculated values using a LFER are shown for comparison between parentheses. "nd" refers to values that could not be determined.

Figure 1.Np sorption to illite $\left(\mathrm{R}_{\mathrm{d}}\right.$, in $\left.\mathrm{L} / \mathrm{kg}\right)$ versus $\mathrm{pH}$ measured for different reaction time (7, 21, 35, 63 days) and a Np total concentration of (a) $10^{-6} \mathrm{M}$ and (b) $3 \times 10^{-8} \mathrm{M}$. (c) Results obtained for $\mathrm{pH}=7.2 \pm 0.2$ are plotted as $\log \mathrm{R}_{\mathrm{d}}$ versus $[\mathrm{Np}]_{\text {tot. }}$.

Figure 2. The present $\mathrm{Np}$-illite sorption isotherm for $\mathrm{pH}=7.2 \pm 0.2$, fitted with a Freundlich equation, is compared with literature data for other cations (noted "M") sorption to illite (Eu(III), Ni(II), Sr(II); Poinssot et al., 1999; Bradbury and Baeyens, 2009a,b) and U(VI) sorption to montmorillonite (noted "U(VI)-MONT"; Marques-Fernadez et al., 2012). Dotted line shows the illite and montmorillonite strong binding sites surface density $\left(2 \times 10^{-3} \mathrm{~mol} / \mathrm{kg}\right)$ considered in the 2 SPNE SC/CE model.

Figure 3. $\mathrm{Np}$ sorption to illite $\left(\mathrm{R}_{\mathrm{d}}\right.$, in $\left.\mathrm{L} / \mathrm{kg}\right)$ versus $\mathrm{pH}$ measured for a $\mathrm{Np}$ total concentration of $1.2 \times 10^{-7} \mathrm{M}$ and compared with literature $\mathrm{Np}(\mathrm{V})$ - and $\mathrm{Th}(\mathrm{IV})$-illite sorption data (Gorgeon, 1994; Bradbury and Beyens, 2009b). The present experimental conditions are comparable to the one of Gorgeon (1994), except that the results were obtained in ambient atmosphere in the latter study. 
Figure 4. $\log \mathrm{R}_{\mathrm{d}}$ versus the apparent electron activity pe $\left(=-\log \mathrm{a}_{\mathrm{e}-}=16.9 \mathrm{Eh}(\mathrm{V})\right)$ for $\mathrm{pH}=$ $7.2 \pm 0.2$

Figure 5.pH-pe (or Eh on the secondary scale) diagram of Neptunium in $0.1 \mathrm{M} \mathrm{NaCl}$ solution. Experimental results are presented as black squares for the batch experiments and large white circles for the two samples analyzed by XANES. The formation of $\mathrm{NpO}_{2(\mathrm{am})}$ is also included in the calculations for the lowest and the highest $[\mathrm{Np}]_{\text {tot }}$ investigated $\left(3 \times 10^{-8}\right.$ and $\left.3 \times 10^{-4} \mathrm{M}\right)$ and its predominance field is delimited by grey dotted lines.

Figure 6.(a) $\mathrm{Np}$ L3-XANES measured for a Np-illite sample prepared at $\mathrm{pH}=7.4$ and 9.6([Np $\left.]_{\text {tot }}=3 \times 10^{-4} \mathrm{M}, \mathrm{m} / \mathrm{V}=20 \mathrm{~g} / \mathrm{L}, \mathrm{Eh}=0.40 \pm 0.05 \mathrm{~V}\right)$. Reference XANES of aqueous $\mathrm{Np}(\mathrm{IV})$ and $\mathrm{Np}(\mathrm{V})$ in $1 \mathrm{M} \mathrm{HClO}_{4}$ from Gaona et al. (2012) are shown for comparison. Arrows highlight a $\mathrm{Np}(\mathrm{V})$ reduction to $\mathrm{Np}(\mathrm{IV})$ process in the present study. The area between 17610 and $17670 \mathrm{eV}$ is enlarged in (b).

Figure 7. Experimental $\log \mathrm{R}_{\mathrm{d}}$ (black circles) and the corresponding calculated values (white circles) with the fitted surface complexation constants for $\mathrm{Np}(\mathrm{IV})$ with illite versus $\mathrm{pH}$ for $[\mathrm{Np}]_{\mathrm{tot}}=10^{-6}(\mathrm{a}), 10^{-7}(\mathrm{~b})$ and $3 \times 10^{-8} \mathrm{M}$ (c). The corresponding redox (pH-pe/Eh plot) conditions are shown on the right side with the predominance diagram for aqueous Np species (d) (e) (f). Lines represent calculations made for constant $\mathrm{pH}+\mathrm{pe}$ (bold line) \pm 0.8 (lower limit: bold dashed line; upper limit: thin dashed line).

Figure 8. The predicted $\mathrm{Np}(\mathrm{IV})$-illite $\mathrm{pH}$-edge (log $\mathrm{R}_{\mathrm{d}} \mathrm{vs} \mathrm{pH}$ ) with the presently determined constants is compared with the experimental pH-edge of $\mathrm{Th}(\mathrm{IV})$ and $\mathrm{Sn}(\mathrm{IV})$. Dotted lines represent the uncertainty on the determined surface complexation constants for $\mathrm{Np}$ (IV)-illite.

Figure 9. On the pH-pe (or Eh on the secondary scale) diagram of Neptunium in $0.1 \mathrm{M} \mathrm{NaCl}$ solution presented in fig. 5 , is superimposed $\mathrm{Np}$ predominance diagram calculated at the illite surface. It shows that the $\mathrm{Np}(\mathrm{V}) / \mathrm{Np}(\mathrm{IV})$ borderline at the illite surface is between 3 and 5 pe 
units $(0.18-0.30 \mathrm{~V})$, depending on the $\mathrm{pH}$, higher than the corresponding one in solution. Experimental $\mathrm{pH}$-pe values are also plotted (without error bars for clarity), showing that in the present batch experiments, $\mathrm{Np}(\mathrm{V})$ prevails in solution whereas and $\mathrm{Np}(\mathrm{IV})$ prevails at the surface, explaining the stronger $\mathrm{Np}$-illite sorption observed compared with literature, under aerobic condition. 
$\log \mathrm{K}(\mathrm{I}=0)$

\begin{tabular}{|c|c|}
\hline $\mathrm{NpO}_{2}^{+}+4 \mathrm{H}^{+}+\mathrm{e}^{-}=\mathrm{Np}^{4+}+2 \mathrm{H}_{2} \mathrm{O}$ & 10.21 \\
\hline $\mathrm{NpO}_{2}^{+}+\mathrm{H}_{2} \mathrm{O}=\equiv \mathrm{NpO}_{2} \mathrm{OH}+\mathrm{H}^{+}$ & -11.3 \\
\hline $\mathrm{NpO}_{2}^{+}+2 \mathrm{H}_{2} \mathrm{O}=\equiv \mathrm{NpO}_{2}(\mathrm{OH})_{2}^{-}+2 \mathrm{H}^{+}$ & -23.6 \\
\hline $\mathrm{Np}^{4+}+\mathrm{H}_{2} \mathrm{O}=\mathrm{NpOH}^{3+}+\mathrm{H}^{+}$ & 0.55 \\
\hline $\mathrm{Np}^{4+}+2 \mathrm{H}_{2} \mathrm{O}=\mathrm{Np}(\mathrm{OH})_{2}{ }^{2+}+2 \mathrm{H}^{+}$ & 0.35 \\
\hline $\mathrm{Np}^{4+}+3 \mathrm{H}_{2} \mathrm{O}=\mathrm{Np}(\mathrm{OH})_{3}^{+}+3 \mathrm{H}^{+}$ & $-2.3(\mathrm{Pu})$ \\
\hline $\mathrm{Np}^{4+}+4 \mathrm{H}_{2} \mathrm{O}=\mathrm{Np}(\mathrm{OH})_{4}+4 \mathrm{H}^{+}$ & -8.3 \\
\hline $\mathrm{NpO}_{2(\mathrm{am})}+2 \mathrm{H}_{2} \mathrm{O}=\mathrm{Np}^{4+}+4 \mathrm{OH}^{-}$ & -56.7 \\
\hline $\mathrm{X}-\mathrm{Na}+\mathrm{NpO}_{2}^{+}=\mathrm{X}-\mathrm{NpO}_{2}$ & \\
\hline$\equiv \mathrm{SOH}+\mathrm{H}^{+}=\equiv \mathrm{SOH}_{2}^{+}$ & $4^{\mathrm{f}}$ \\
\hline$\equiv \mathrm{SOH}=\equiv \mathrm{SO}^{-}+\mathrm{H}^{+}$ & $-6.2^{f}$ \\
\hline$\equiv \mathrm{SOH}+\mathrm{NpO}_{2}^{+}=\equiv \mathrm{SO}-\mathrm{NpO}_{2}+\mathrm{H}^{+}$ & $-2.0^{\mathrm{f}}$ \\
\hline$\equiv \mathrm{SOH}+\mathrm{NpO}_{2}^{+}+\mathrm{H}_{2} \mathrm{O}=\equiv \mathrm{SO}-\mathrm{NpO}_{2} \mathrm{OH}^{-}+2 \mathrm{H}^{+}$ & $-10.3^{\mathrm{f}}$ \\
\hline$\equiv \mathrm{SOH}+\mathrm{Np}^{4+}=\equiv \mathrm{SO}-\mathrm{Np}^{3+}+\mathrm{H}^{+}$ & nd $(8.4 \pm 0.6)$ \\
\hline$\equiv \mathrm{SOH}+\mathrm{Np}^{4+}+\mathrm{H}_{2} \mathrm{O}=\equiv \mathrm{SO}-\mathrm{NpOH}^{2+}+2 \mathrm{H}^{+}$ & nd $(8.2 \pm 0.7)$ \\
\hline$\equiv \mathrm{SOH}+\mathrm{Np}^{4+}+2 \mathrm{H}_{2} \mathrm{O}=\equiv \mathrm{SO}-\mathrm{Np}(\mathrm{OH})_{2}^{+}+3 \mathrm{H}^{+}$ & $6.4 \pm 1.2(6.0 \pm 0.7)$ \\
\hline$\equiv \mathrm{SOH}+\mathrm{Np}^{4+}+3 \mathrm{H}_{2} \mathrm{O}=\equiv \mathrm{SO}-\mathrm{Np}(\mathrm{OH})_{3}+4 \mathrm{H}^{+}$ & $0.7 \pm 1.3(1.0 \pm 1.1)$ \\
\hline$\equiv \mathrm{SOH}+\mathrm{Np}^{4+}+4 \mathrm{H}_{2} \mathrm{O}=\equiv \mathrm{SO}-\mathrm{Np}(\mathrm{OH})_{4}^{-}+5 \mathrm{H}^{+}$ & $-5.7 \pm 1.2(\mathrm{nd})$ \\
\hline
\end{tabular}

\section{Table 1}



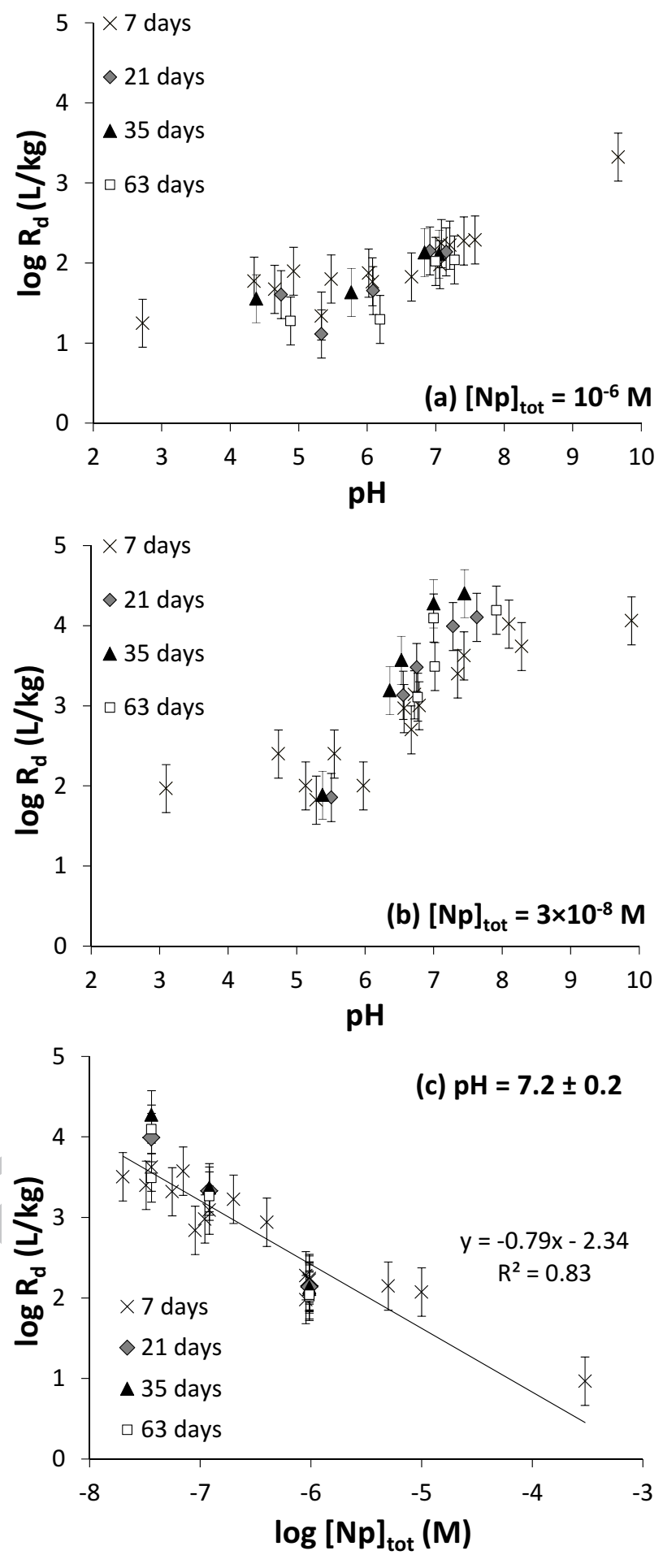

Figure 1 


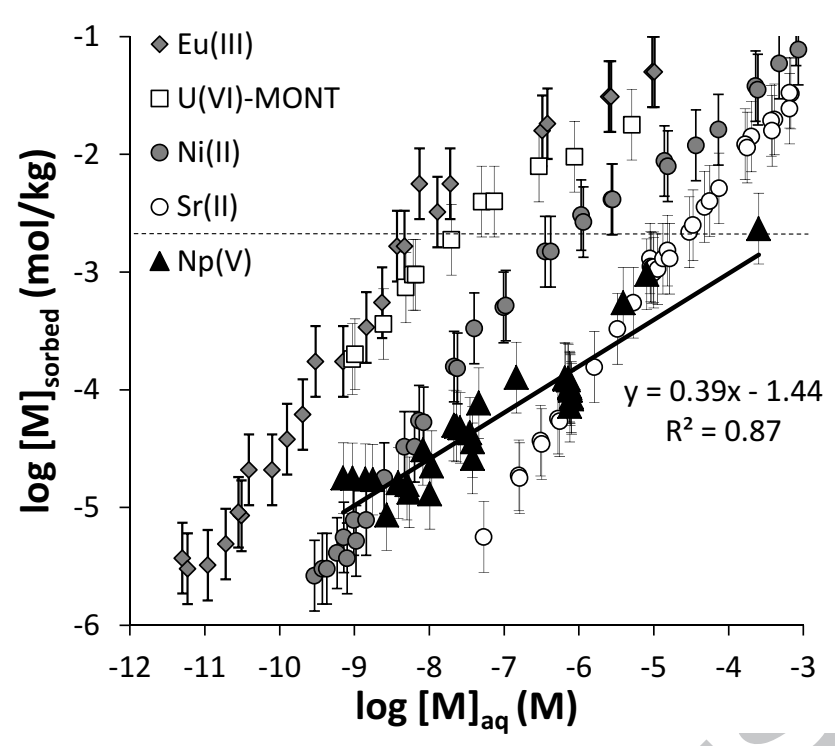

Figure 2

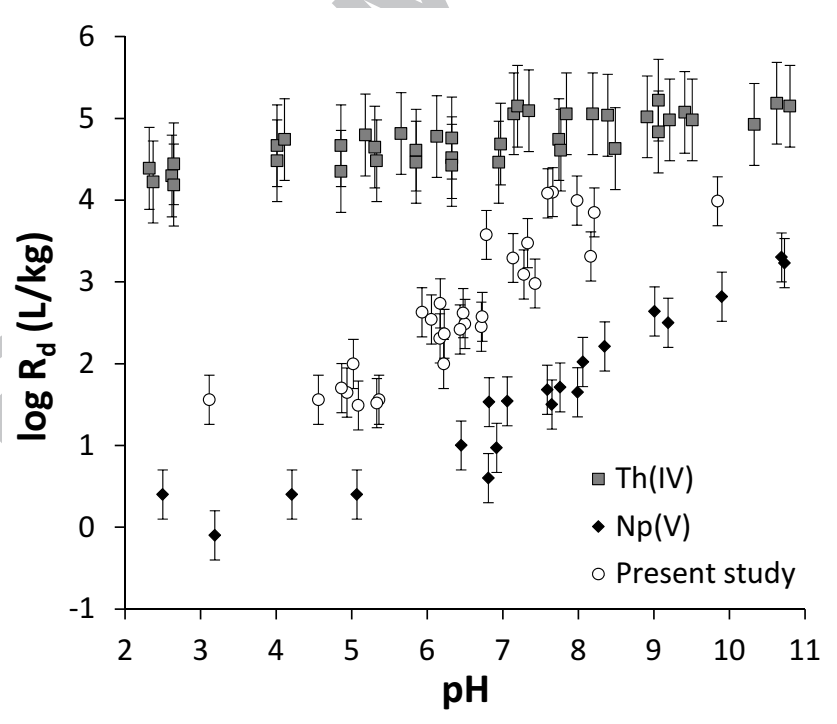

Figure 3 


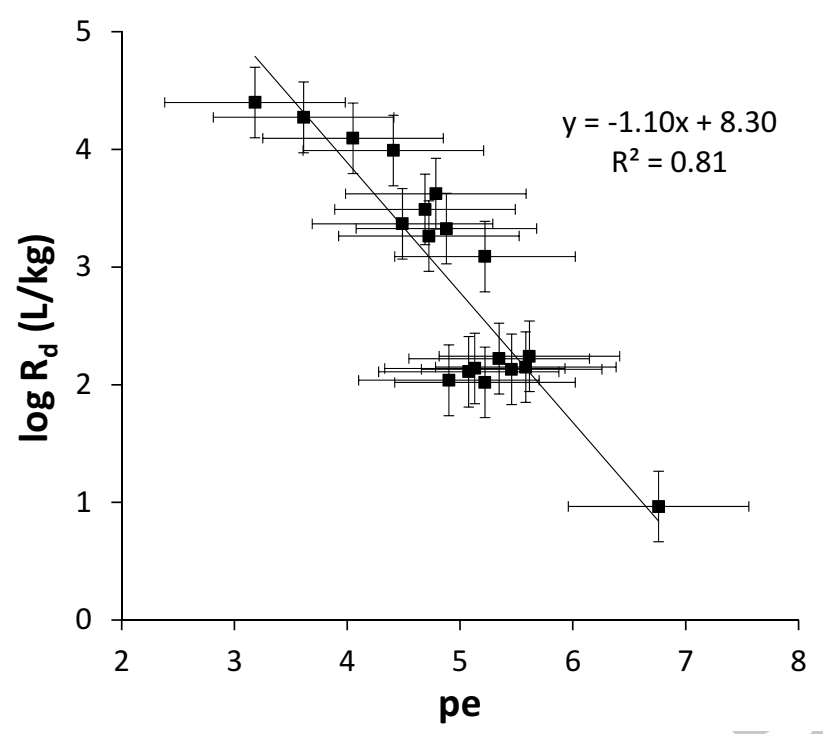

Figure 4

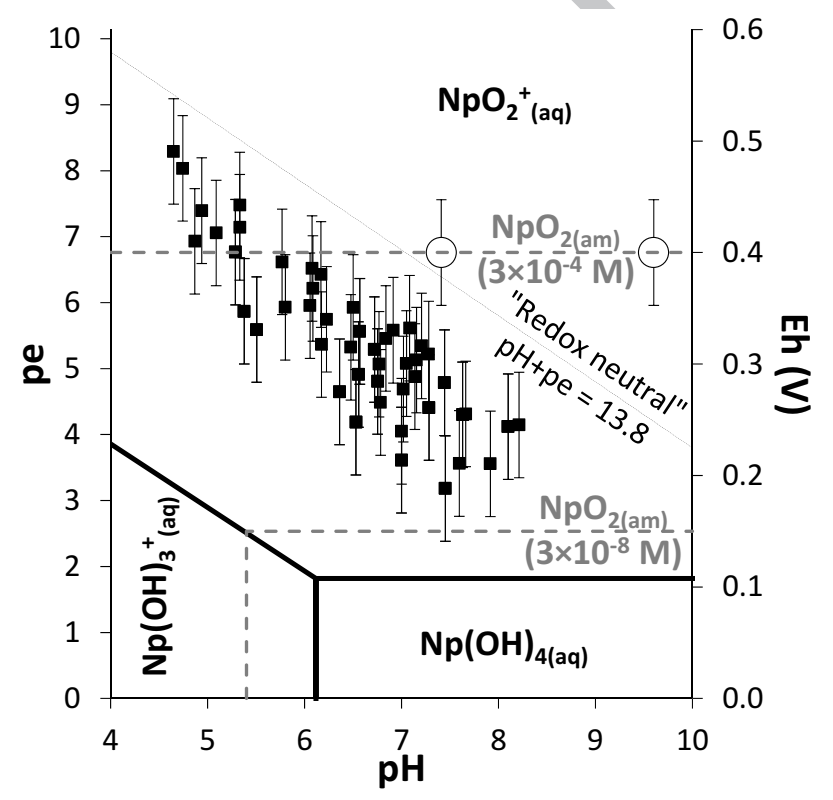

Figure 5 

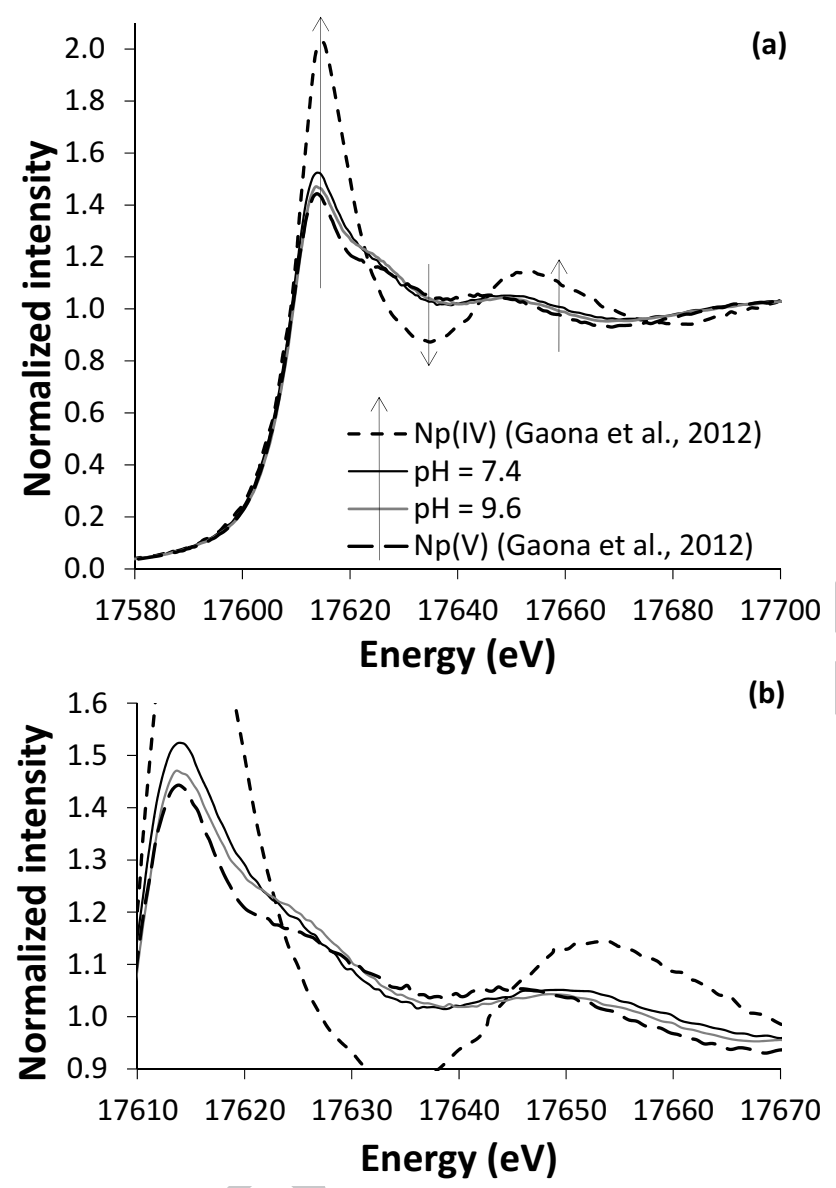

Figure 6 

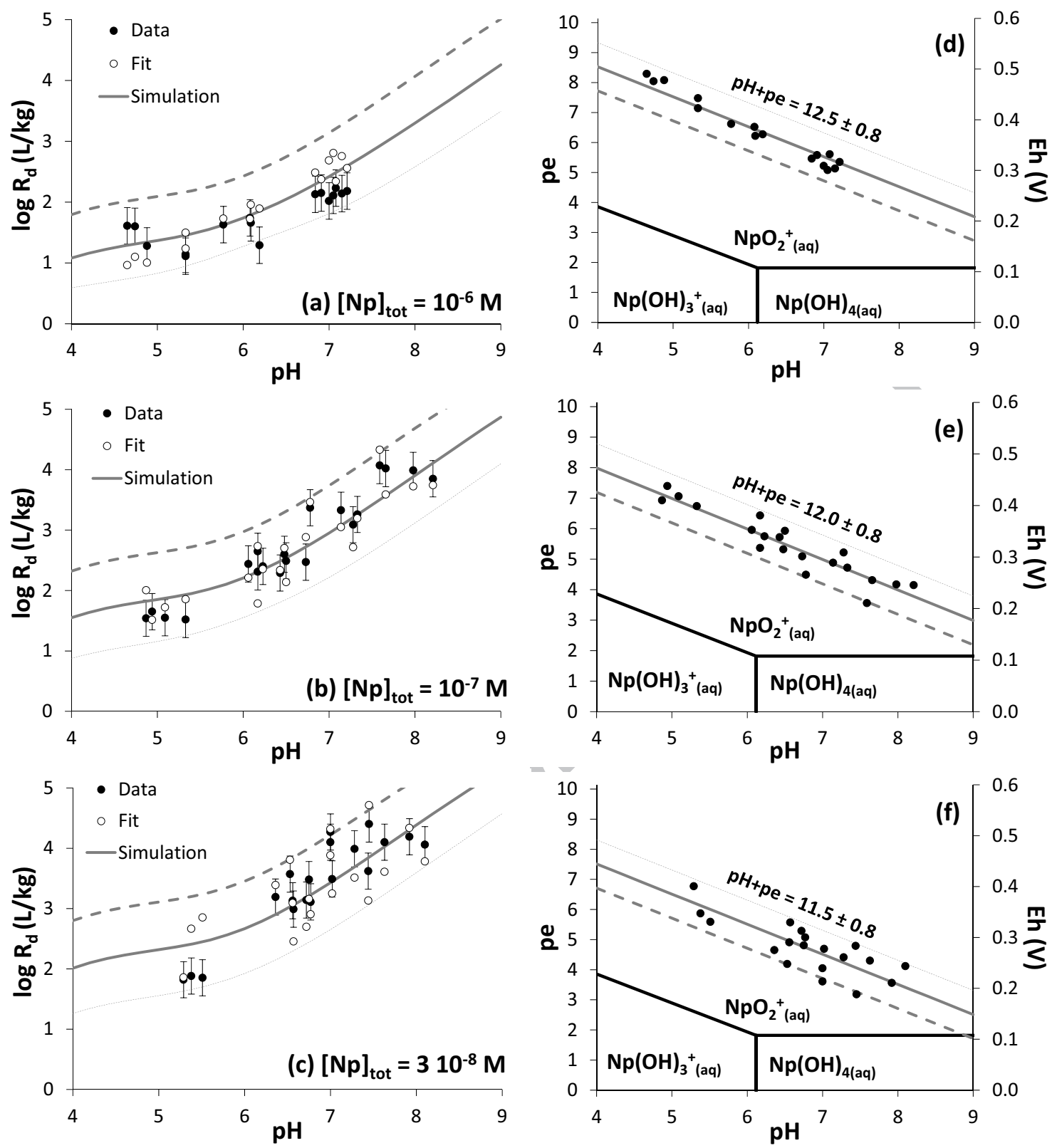

Figure 7 


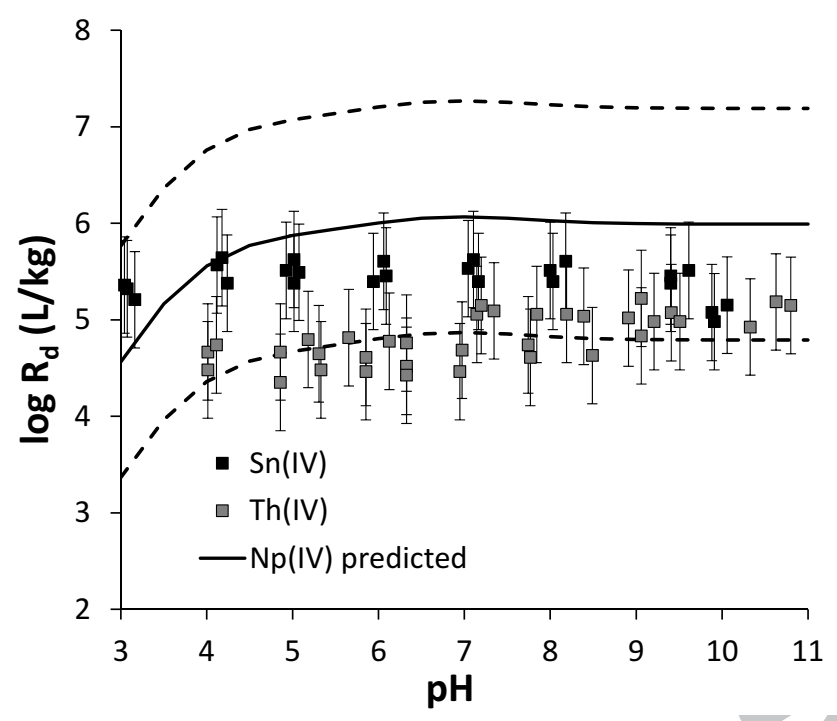

Figure 8

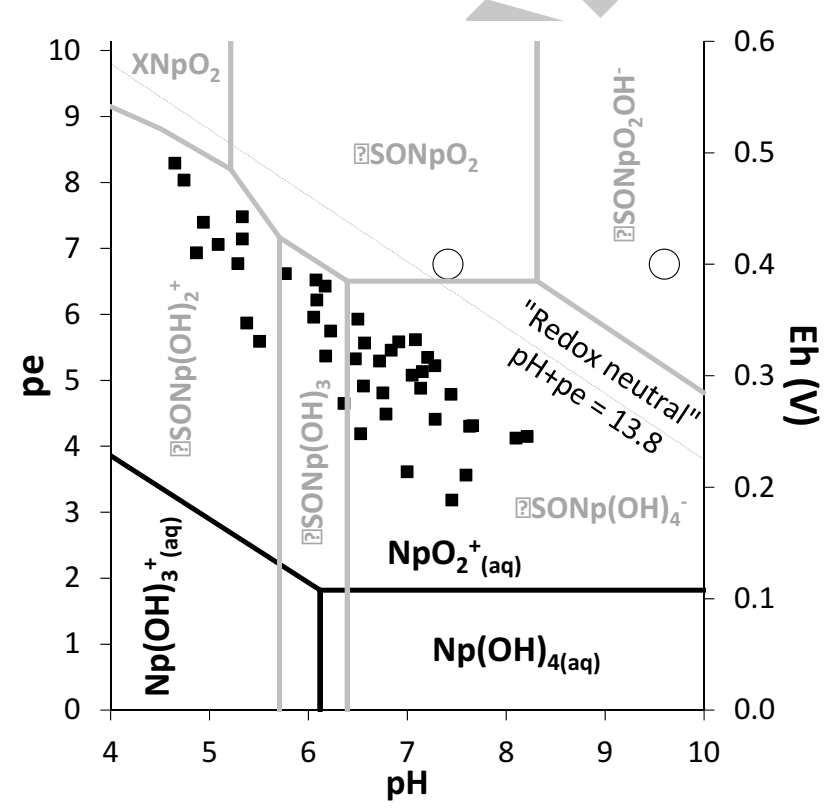

Figure 9 